\title{
Processing of pre-cooked frozen Brussels sprouts: Heat transfer modelling as related to enzyme inactivation and quality stability
}

\author{
John Pérez-Calderón ${ }^{a}$, María Victoria Santos ${ }^{c}$, Noemí Zaritzky $^{a, b, *}$ \\ a Centro de Investigación y Desarrollo en Criotecnología de Alimentos CIDCA (UNLP-CONICET-CIC), Calle 47 y 116, \\ La Plata, CP 1900, Argentina \\ b Depto. de Ingeniería Química, Facultad de Ingeniería, Universidad Nacional de La Plata, Calle 1 y 47, CP 1900, La \\ Plata, Argentina \\ c Instituto Andino Patagónico de Tecnologías Biológicas y Geoambientales (IPATEC) CONICET Quintral 1250, \\ Bariloche, Argentina
}

\section{A R T I C L E I N F O}

\section{Article history:}

Received 5 June 2019

Received in revised form 27 August

2019

Accepted 11 September 2019

Available online 18 September 2019

\section{Keywords:}

Pre-cooked frozen vegetables Peroxidase inactivation kinetics

Finite elements

Mathematical modeling

Process optimization

\begin{abstract}
A B S T R A C T
The finite element numerical method was applied to simulate heat transfer processes (heating, cooling and freezing) in irregular domains during the production of precooked frozen Brussels sprouts; the effect of temperature on thermo-physical properties in the partial differential equation, and experimental heat transfer coefficients were considered. During precooking, heat transfer was coupled to the inactivation kinetics of thermo-labile and thermo-resistant fractions of peroxidase. The temperature distribution, and enzyme activity in the vegetable domain were modeled; these simulations were validated, obtaining a satisfactory agreement between the predicted values and: (i) the experimental time-temperature curves, (ii) the residual enzyme activity of peroxidase measured in the vegetable.

The simulation of the time-temperature curve during the freezing process is a complex nonlinear problem that requires knowledge of the thermo physical properties changing with temperature. A change of variables based on Enthalpy and Kirchhoff formulations, was adopted for the numerical solution. The effects of precooking times (3,6,10 min) on quality parameters of the frozen vegetable (Browing Index, textural properties, residual peroxidase activity, ascorbic acid content) were measured in the samples after freezing and storage during 4 months at $-20^{\circ} \mathrm{C}$. The pre-cooking time was optimized to get acceptable quality parameters avoiding peroxidase reactivation during frozen storage.
\end{abstract}

(c) 2019 Institution of Chemical Engineers. Published by Elsevier B.V. All rights reserved.

\section{Introduction}

Brussels sprouts (Brassica olareacea L. gemmifera) have numerousbeneficial compounds such a considerable amount of vitamin C (ascorbic acid) which have made them attractive for consumers (Gebhardt and Thomas, 2002). These vegetables that belong to the mustard family
(Brassicaceae) have the characteristic feature of containing naturally occurring glucosinolates. Foods containing glucosinolates, (cruciform vegetables) exhibit anti-inflammatory, antioxidant, chemoprotective, anticancer, and immune system-enhancing properties (Glade and Meguid, 2015; Herr et al., 2013).

Brussels sprouts exports totaled US $\$ 181.8$ million in 2017 ; the value of exported Brussels sprouts increased by $0.9 \%$ from 2016 to 2017 . The

Abbreviations: AA, ascorbic acid; Ea, activation energy; EA, enzymatic activity; EC, enzyme commission number; FEM, finite element method; LOX, lipoxygenase; PC, after the pre-cooking and cooling stage; PCFS, precooked, frozen and stored; POD, peroxidase; PPO, polyphenoloxidase; RMSE, root mean square error; SD, standard deviation.

* Corresponding author at: CIDCA- Fac. Cs. Exactas UNLP, Calle 47 y 116, La Plata 1900 Argentina.

E-mail addresses: zaritzkynoemi@gmail.com, zaritzky@ing.unlp.edu.ar (N. Zaritzky).

https://doi.org/10.1016/j.fbp.2019.09.003

0960-3085/@ 2019 Institution of Chemical Engineers. Published by Elsevier B.V. All rights reserved. 


$\begin{array}{ll}\text { Nomenclature } \\ \mathrm{C} & \text { Enzyme concentrations } \\ \mathrm{CG} & \text { Global capacitance matrix } \\ \mathrm{C}_{\mathrm{p}} & \text { Specific heat } /\left(\mathrm{kg}^{\circ} \mathrm{C}\right) \\ \mathrm{C}_{\mathrm{pap}} & \text { Apparent specific heat } /\left(\mathrm{kg}^{\circ} \mathrm{C}\right) \\ \mathrm{D} & \text { Diameter } \\ \mathrm{E} & \text { Kirchhoff function }(\mathrm{W} / \mathrm{m}) \\ \mathrm{FG} & \text { Global force vector } \\ \mathrm{Fm} & \text { Maximum puncture force }(\mathrm{N}) \\ \mathrm{H} & \text { Volumetric enthalpy }\left(\mathrm{J} / \mathrm{m}^{3}\right) \\ \mathrm{h} & \text { Surface heat transfer coefficient }\left(\mathrm{W} / \mathrm{m}^{2}{ }^{\circ} \mathrm{C}\right) \\ \mathrm{k} & \text { Thermal conductivity }\left(\mathrm{W} / \mathrm{m}^{\circ} \mathrm{C}\right) \\ \mathrm{KG} & \text { Global conductance matrix } \\ \mathrm{MG} & \text { Global convective matrix } \\ \mathrm{N} & \text { Vector containing the shape functions } \\ \mathrm{N}_{\mathrm{j}} & \text { Shape function } \mathrm{j} \\ \mathrm{S} & \text { Stiffness }(\mathrm{N} / \mathrm{mm}) \\ \mathrm{t} & \text { Time (s) } \\ \mathrm{T} & \text { Temperature }\left({ }^{\circ} \mathrm{C}\right) \\ \mathrm{T}_{\text {ext }} & \text { External fluid temperature }\left({ }^{\circ} \mathrm{C}\right) \\ \mathrm{T}_{\mathrm{f}} & \text { Initial freezing temperature }\left({ }^{\circ} \mathrm{C}\right) \\ \mathrm{T}_{\text {ref }} & \text { Reference temperature }\left({ }^{\circ} \mathrm{C}\right) \\ \mathrm{v} & \text { Fluid velocity }(\mathrm{m} / \mathrm{s}) \\ \mathrm{x} & \text { Mass fraction } \\ \mathrm{xb} & \text { Unfrozen water fraction }(\mathrm{g} \text { of bound water/g of } \\ & \text { total mass) } \\ & \end{array}$

\section{Greeks letters}

$\begin{array}{ll}\Delta \mathrm{t} & \text { Time interval }(\mathrm{s}) \\ \varepsilon & \text { Porosity } \\ \rho & \text { Density }\left(\mathrm{kg} / \mathrm{m}^{3}\right) \\ \Omega & \text { Domain } \\ \alpha & \text { Isoenzyme fraction } \\ \beta & \text { Volumetric expansion coefficient }\left(\mathrm{K}^{-1}\right) \\ \mu & \text { Viscosity }(\mathrm{Kg} / \mathrm{m} \mathrm{s})\end{array}$

\section{Subscripts}

$0 \quad$ Initial

b Bound water

e Element

e1 Border element

$\mathrm{h}$ Mass fraction of ice

L Thermo-labile isoenzyme

$\mathrm{R} \quad$ Thermo-resistant isoenzyme

w Water

\section{Superscripts}

$\begin{array}{ll}\text { i } & \text { Component } \\ \text { S } & \text { Solid matrix } \\ \text { T } & \text { Transpose of a vector or a matrix }\end{array}$

five countries that exported the highest dollar value worth of Brussels sprouts during 2017 were: Netherlands $(40.9 \%$ of total Brussels sprouts exports), Mexico (28.9\%), United States(12.8\%), Belgium (5.2\%), Canada (2\%) (Workman, 2018).

The frozen vegetable market in 2017 was valued at $\$ 26,479.0$ million, and is expected to reach a total of $\$ 38,845.7$ million by 2025 , registering a compound annual growth rate (CAGR) of 5.0\% from 2018 to 2025 (Sumes and Deshmukh, 2018).

It is widely known that enzyme activity causes loss of quality and irreversible deterioration in raw and underblanched vegetables
(Müftügil, 1985). These detrimental effects include discoloring, loss of flavor and development of off-odors during frozen storage.

In order to commercialize frozen Brussels sprouts a previous thermal treatment is needed in order to inactivate certain enzymes responsible for quality and nutrient losses. The precooking stage in Brussels sprouts involves a thermal treatment and a cooling process; afterwards they are submitted to freezing and cold storage.

Enzymes such as lipoxygenase, peroxidase and polyphenoloxidase are oxidoreductases present in vegetable tissues.

The presence of polyphenoloxidase (PPO; EC 1.14.18.1) produces browning that is associated to mechanical and physical stresses that occur during the post-harvest process and storage. PPO in presence of oxygen generates the oxidation of phenolic compounds such as o-diphenols; this reaction produces o-quinones, which subsequently polymerize with others o-quinones, phenolic substances, proteins, and/or amino acids to produce brown pigments (Murasaki-Aliberti et al., 2009). Since Brussels sprouts do not suffer mechanical stress, PPO is not usually selected as an index of the precooking stage.

Lipoxygenase (LOX; EC 1.13.11.12) catalyzes the bioxygenation of polyunsaturated fatty acids containing a cis,cis-1,4-pentadiene unit to form conjugated hydroperoxydienoic acids. It has been linked to the development of off-flavors and odor production, loss of pigments such as carotenes and chlorophylls, and destruction of essential fatty acids (Szymanowska et al., 2009).

Peroxidase (POD; EC 1.11.1.7), is a glycoprotein whose primary function is to oxidize phenolic compounds in presence of $\mathrm{H}_{2} \mathrm{O}_{2}$. POD is a hemeprotein that catalyzes the nonenzymatic, peroxidative degradation of unsaturated fatty acids yielding volatile and flavorful carbonyl compounds that may contribute to oxidized flavor (Rodriguez-Saona et al., 1995; Richardson and Hyslop, 1985). It has been reported that POD is responsible not only for off-flavors but also for browning discoloration and nutritional damage (Lagrimini et al., 1993). POD generates a dark coloring when present in a vegetable tissue and it is usually the enzyme of choice when trying to monitor the process, since it facilitates the quantification of the enzyme throughout the thermal processing. However, its complete inactivation may result in overblanching (Williams et al., 1986).

Pérez-Calderón et al. (2017) determined the thermal inactivation kinetic parameters of LOX and POD in Brussels sprouts and broccoli, showing a biphasic behavior with thermo-labile and thermo-resistant fractions of isoenzymes. In that work the authors reported that after thermal treatment and frozen storage, POD was the enzyme that exhibited the highest influence on quality deterioration of frozen Brussels sprouts.

The numerical simulation and optimization of each stage during the production of precooked frozen Brussels sprouts is useful for food engineers since it minimizes energy costs by accurately determining precooking and freezing times. The precooking and freezing processes can be described by heat transfer phenomena and the required input data are thermo-physical parameters as well as surface heat transfer coefficients.

The finite element method (FEM) is a numerical method that allows to obtain the time temperature curve at each point in the irregular domain (vegetable) as the precooking and freezing process evolves.

During the precooking stage (which includes thermal treatment and a cooling process) the coupling of the enzyme inactivation kinetics is of great importance in order to determine the degree of residual enzyme activity of peroxidase, and to correlate this information with quality parameters such as browning index and ascorbic acid content.

Literature reports concerning the numerical modeling of protein inactivation coupled with mass and energy transfer during skim milk production have been reported Jaskulski et al. (2017). This model used CFD technique to establish the thermal degradation of components (proteins) during the process, determining the average concentration of protein in powders after spray drying.

There is scant published literature on numerical simulations of precooking and cooling of Brussels sprouts coupled with enzyme inactivation kinetics of POD considering the irregular shape of the vegetable. 
Additionally, in the simulation of the freezing process the phase change transition of water into ice in the foodstuff leads to thermo-physical properties that are strongly temperature dependent, establishing a highly nonlinear mathematical problem. A change in the variables of the heat transfer partial differential equation in terms of Enthalpy and Kirchhoff formulation enables the determination of freezing times using finite elements. Previous publications showed that the numerical method led to an excellent convergence and a satisfactory agreement between experimental measurements and numerical predictions in different food systems (Dima et al., 2014; Santos et al., 2010; Santos and Lespinard, 2011).

The objectives of the present work are: (a) to determine experimentally the heat transfer coefficients and the specific heat of Brussels sprouts in a wide range of temperatures that include precooking, cooling and freezing stages; (b) to numerically simulate by using the finite element method (FEM) the time-temperature curves during precooking stage (thermal treatment and cooling) of Brussels sprouts; (c) to calculate the residual enzyme activity after precooking stage by coupling the enzyme inactivation kinetics of POD and the heat transfer program ; (d) to validate the mathematical simulation with experimental time-temperature curves and residual POD enzyme activity; (e) to simulate using FEM, the freezing stage of precooked Brussels sprouts by reformulating the heat transfer equation in terms of enthalpy and Kirchhoff functions; (f) to determine the optimum conditions to obtain high quality frozen precooked Brussels sprouts, analyzing the effect of precooking times on residual POD activity, browning index and ascorbic acid content, after frozen storage.

\section{Materials and methods}

\subsection{Vegetable samples and proximate composition}

Brussels sprouts (Brassica oleracea L. var gemmifera) were purchased from agricultural producers of field-grown in the horticultural zone of La Plata city (Buenos Aires Province, Argentina) between the months of May and June 2017, 2018. The average weight of the sprout heads was $17.8 \pm 0.9 \mathrm{~g}$. Moisture content was determined by the indirect method of drying the sample in a vacuum oven LiTekvo model DZF-6030A (LiTekvo Instruments, Minhang District, Shanghai, China) at $70^{\circ} \mathrm{C}$ and reduced pressure of $100 \mathrm{mmHg}$ to a constant dry weight (AOAC, 2010). The crude protein content was determined by Kjeldahl method (AOAC, 2010) using an appropriate factor for these vegetables (6.25) to convert total nitrogen to crude protein (Lisiewska et al., 2009). Fat was determined using the Soxhlet extraction method with ethyl ether (AOAC, 2010). Ash content was obtained by calcination of the samples in a muffle at $550^{\circ} \mathrm{C}$ for $8 \mathrm{~h}$ (AOAC, 2010). Carbohydrates and fibers were determined by difference.

\subsection{Thermal treatment and cooling of the vegetables. Precooking Stage}

Several Brussels sprouts were heated in a stirred thermostatic bath Techne Model FTE-10DDC (Bibby-scientific Ltda, Stone Staffordshire, United Kingdom) recording temperature vs. time curves using thermocouples placed axially at the center inside the product. To avoid flotation the Brussels sprouts were placed in a canister attached to sinkers. The water temperature of the thermostatic bath was fixed at 80,85 , or $90^{\circ} \mathrm{C}$ during each experiment.

After specific times $(3,6$, or $10 \mathrm{~min})$ the vegetables were immediately placed in an ice-water bath to stop the heating process. This is the usual process recommended by Barbosa-Cánovas et al. (2005). The thermocouples (Type T Copper/Constantan) used in the experiments were connected to an acquisition system (TESTO175, TESTO AG, Germany) where the thermal histories were stored.

To determine the coordinates of the thermocouples in the Brussels sprouts the vegetable was maintained at a fixed position vertically; a caliper was used to measure diameters and heights of all the vegetables to locate the central point. At the opposite end of the stem a small needle was inserted until reaching the half-height of sample. The needle enabled the thermocouple to be easily inserted in the Brussels sprout with minimum radial movement recording the temperature history in a defined point. When the experiment was finished the vegetable was cut and the position of the thermocouple was measured again to evaluate eventual displacements in the vegetables

\subsection{POD inactivation during the precooking stage of vegetables}

The enzyme activity measurements consist of mixing a vegetable extract with a specific substrate for each enzyme. Determination of the enzymatic activity (EA) of POD was assessed spectrophotometrically according to the method described by Morales-Blancas et al. (2002) by mixing $0.120 \mathrm{~mL}$ of enzyme extract with $3.5 \mathrm{~mL}$ of the substrate solution. Enzyme inactivation assays were carried out by immersing vegetable extracts in a thermostatic water bath Techne Model FTE-10DDC (Bibby-scientific Ltda, Stone Staffordshire, United Kingdom) at three different temperatures $\left(75,80,90^{\circ} \mathrm{C}\right)$, with contact times ranging between $50-400 \mathrm{~s}$. Afterwards, samples were immediately immersed into an ice-water bath $\left(0^{\circ} \mathrm{C}\right)$ to stop the enzyme inactivation process, minimizing the cooling time.

The extract and substrate for POD inactivation assay was thoroughly described in Pérez-Calderón et al. (2017). Brussels sprouts showed a biphasic behavior of POD, which indicates that isoenzymes with different thermal stability are present within the vegetable. This biphasic behavior of the POD was also observed for Broccoli (Morales-Blancas et al., 2002).

The thermal inactivation kinetic parameters such as the rate constants for the labile $\left(\mathrm{k}_{\mathrm{L}}\right)$ and resistant $\left(\mathrm{k}_{\mathrm{R}}\right)$ fractions, at different temperatures and activation energies (Ea) were previously determined and reported by Pérez-Calderón et al. (2017). The reported parameters of POD thermal inactivation in Brussels sprouts were: $\mathrm{Ea}_{\mathrm{L}}=62.5 \mathrm{~kJ} / \mathrm{mol}$, (labile fraction) $\mathrm{Ea}_{\mathrm{R}}=56.3 \mathrm{~kJ} / \mathrm{mol}$ (resistant fraction). The kinetic inactivation rate constants at $80^{\circ} \mathrm{C}$ were $\mathrm{k}_{\mathrm{L}}=4.24 \times 10^{2} \mathrm{~s}^{-1}$, $\mathrm{k}_{\mathrm{R}}=5.37 \times 10^{3} \mathrm{~s}^{-1}$, and the initial fraction of the heat-resistant enzyme was $\alpha_{R}=25.02 \%$

\subsection{Freezing experiments and frozen storage}

Several samples of precooked and cooled vegetables were placed in a tunnel freezer with circulating air in order to get similar operating conditions to those of the industry. The time-temperature curves at several points inside the product were recorded using a temperature acquisition device (Testo 175, Testo AG, Germany). The cooling air velocity in the tunnel freezer was measured using a hot wire anemometer (TSI model 1650). Afterwards the samples were maintained frozen during 4 months at $-20^{\circ} \mathrm{C}$. 


\subsection{Mathematical modeling and numerical simulations}

The two-dimensional axial symmetric domain of the Brussels sprout was built from images of the samples using the Image Processing Toolbox, MATLAB 6.5 (MathWorks, Natick, Massachusetts), where the contour of the image was approximated with a B-Spline curve; this curve was transformed into a solid object.

Fig. 1a shows an example of a Brussels sprout irregular contour that was approximated as a solid of revolution having a symmetry plane at $r=0$, therefore cylindrical coordinates were implemented. Several Brussels sprouts were simulated and for each vegetable digital photographs were taken to obtain the irregular bidimensional domain; the range of diameters and heights were $29-39 \mathrm{~mm}$ and $30-41 \mathrm{~mm}$, respectively.

By importing this geometry the software generated the discretization into finite elements (bidimensional mesh of the domain) that enables the numerical simulations. The finite element method was applied to simulate the thermal treatment (precooking and cooling stage) and freezing process of a 2D axial symmetric geometry.

A subdomain representing the apical zone of the vegetable was defined in order to simulate the average enzyme activity in the inner region that enables the comparison of predicted and experimental enzyme activities. The diameter of apical zone was $26.6 \mathrm{~mm} \pm 1.8 \mathrm{~mm}$. Fig. $1 \mathrm{~b}$ shows the 3D domain and the inner subdomain corresponding to the apical zone.

\subsubsection{Precooking stage}

In the precooking stage that includes the thermal treatment and cooling of the vegetables before the freezing process, the thermo-physical properties do not suffer abrupt changes with temperature in the range $1-95^{\circ} \mathrm{C}$. The partial differential equation that represents the energy transfer is as follows:

$\rho \mathrm{C}_{\mathrm{p}} \frac{\partial \mathrm{T}}{\partial \mathrm{t}} \mathrm{r}=\frac{\partial}{\partial \mathrm{r}}\left(\mathrm{kr} \frac{\partial \mathrm{T}}{\partial \mathrm{r}}\right)+\frac{\partial}{\partial \mathrm{z}}\left(\mathrm{kr} \frac{\partial \mathrm{T}}{\partial \mathrm{z}}\right)$

This equation is valid in the domain $\Omega$ being $\mathrm{T}$ the temperature, $t$ the time of the process, $\rho$ density, $k$ the thermal conductivity, $C_{p}$ the specific heat of the foodstuff, $r$ and $z$ the geometric coordinates.

The initial and boundary conditions are the following:

$\mathrm{T}=\mathrm{T}_{0} \quad \mathrm{t}=0 \quad$ in $\Omega$

$\left(\frac{\partial \mathrm{T}}{\partial \mathrm{z}} \cdot \mathrm{n}_{\mathrm{z}}+\frac{\partial \mathrm{T}}{\partial \mathrm{r}} \cdot \mathrm{n}_{\mathrm{r}}\right) \mathrm{k}=\mathrm{hj}\left(\mathrm{T}_{\text {ext,j}}-\mathrm{T}\right) \quad \mathrm{t} \geq 0 \quad$ in $\partial \Omega_{1}$

$\left(\frac{\partial T}{\partial z} \cdot n_{z}+\frac{\partial T}{\partial r} \cdot n_{r}\right) k=0 \quad t \geq 0 \quad$ in $\partial \Omega_{2}$

where $\partial \Omega_{1}$ corresponds to the convective interface and $\partial \Omega_{2}$ to the symmetry axis, $\mathrm{n}_{\mathrm{r}}$ and $\mathrm{n}_{\mathrm{z}}$ are normal outward vector components at the radial and axial axis, respectively, $\mathrm{n}$ is the outward-pointing normal unit vector at the surface. $T_{0}$ is the initial temperature, $h_{j}$ is the surface heat transfer coefficient, when $j=1$ the $h$ corresponds to the heating stage (stirred hot water bath) and when $j=2$ the $h$ corresponds to the cooling stage (a stagnant ice-water bath), $T_{\text {ext }}, j$ is the external fluid temperature $(j=1$ temperature of the stirred hot water bath, $\mathrm{j}=2$ temperature of the ice-water bath). The $\mathrm{T}_{\text {ext }}$ and $\mathrm{h}$ change simultaneously when the vegetable finishes the thermal treat- ment and enters the cooling stage at a specific time period $(3$, 6 or $10 \mathrm{~min})$.

The numerical model was solved using the COMSOL Multiphysics $3.5 \mathrm{~b}$ software incorporating the thermo-physical properties, surface heat transfer coefficients, external fluid temperatures. Specific sentences were coded in Matlab language inside COMSOL environment in order to describe the consecutive stages of the precooking process (thermal treatment and cooling stage). These sentences consist of programing the simulation of the thermal treatment which occurs during a specific period of time at an external temperature (ranges of $\mathrm{T}_{\text {ext }}=80-90^{\circ} \mathrm{C}$ ) and with an $\mathrm{h}$ value that corresponds to a stirred thermostatic water bath (forced convection). After these pre-cooking times (3, 6 or $10 \mathrm{~min}$ ) the program switched to the cooling process which requires a new Text (ranges of $\mathrm{T}_{\text {ext }}=0-5^{\circ} \mathrm{C}$ ) with an $\mathrm{h}$ value for the cooling bath (water-ice), which is under natural convection conditions. The program allowed to describe the temperature curve at each point of the vegetable during heating and subsequent cooling, considering non-uniform temperature distribution inside the vegetable when it starts to cool down.

\subsubsection{Coupling enzyme inactivation kinetics with the heat} transfer numerical program

First order kinetics, representing the thermal inactivation rate of each iso-enzyme (heat labile and heat resistant) is described as follows:

$\frac{\mathrm{dC}_{\mathrm{L}}}{\mathrm{dt}}=-\mathrm{k}_{\mathrm{L}} \mathrm{C}_{\mathrm{L}}$

$\frac{d C_{R}}{d t}=-k_{R} C_{R}$

where $C_{L}$ y $C_{R}$ are the enzyme concentrations of the heat labile and heat resistant fraction, respectively, and $\mathrm{k}_{\mathrm{L}}$ and $\mathrm{k}_{\mathrm{R}}$ are the heat labile and heat resistant reaction constants, respectively.

The concentration of the enzyme at $t=0$ and at a given time $\mathrm{t}$ can be written as follows:

$\mathrm{C}_{0}=\mathrm{C}_{\mathrm{OR}}+\mathrm{C}_{\mathrm{OL}}$

$C=C_{R}+C_{L}$

where $\mathrm{C}_{\mathrm{OL}}$ and $\mathrm{C}_{\mathrm{OR}}$ are the initial heat labile and heat resistant enzyme activities, respectively at time $t$ :

$$
\begin{aligned}
& \frac{C}{C_{0}}=\frac{C_{R}+C_{L}}{C_{O R}+C_{O L}}=\left(\frac{C_{L}}{C_{O L}}\right) \frac{C_{O L}}{C_{O R}+C_{O L}}+\left(\frac{C_{R}}{C_{O R}}\right) \frac{C_{O R}}{C_{O R}+C_{O L}} \\
& =\left(\frac{C_{L}}{C_{O L}}\right)\left(1-\alpha_{R}\right)+\left(\frac{C_{R}}{C_{O R}}\right)\left(\alpha_{R}\right)
\end{aligned}
$$

By integrating Eqs. (5)-(6) and using the Arrhenius equations the following is obtained:

$$
\begin{aligned}
& \frac{\mathrm{C}_{\mathrm{L}}}{\mathrm{C}_{\mathrm{OL}}}=\exp \left(-\mathrm{k}_{\mathrm{L}} \int_{0}^{\mathrm{tp}} \exp \left(\frac{-\mathrm{Ea} \mathrm{L}_{\mathrm{L}}}{\mathrm{R}}\left[\frac{1}{\mathrm{~T}(\mathrm{r}, \mathrm{z}, \mathrm{t})}-\frac{1}{\mathrm{~T}_{\mathrm{REF}}}\right]\right) \mathrm{dt}\right) \\
& \frac{\mathrm{C}_{\mathrm{R}}}{\mathrm{C}_{\mathrm{OR}}}=\exp \left(-\mathrm{k}_{\mathrm{R}} \int_{0}^{\mathrm{tp}} \exp \left(\frac{-E a_{R}}{\mathrm{R}}\left[\frac{1}{\mathrm{~T}(\mathrm{r}, \mathrm{z}, \mathrm{t})}-\frac{1}{\mathrm{~T}_{\mathrm{REF}}}\right]\right) \mathrm{dt}\right)
\end{aligned}
$$

where Ea is the activation energy, $\mathrm{k}$ is the reaction constant; subscripts $\mathrm{R}$ (resistant) or L (labile) correspond to the resistant or labile fractions. $T_{R E F}$ is the reference temperature given in $(\mathrm{K})$ which in this work was $\mathrm{T}_{\mathrm{REF}}=353.15 \mathrm{~K}, \mathrm{R}$ is the gas constant 


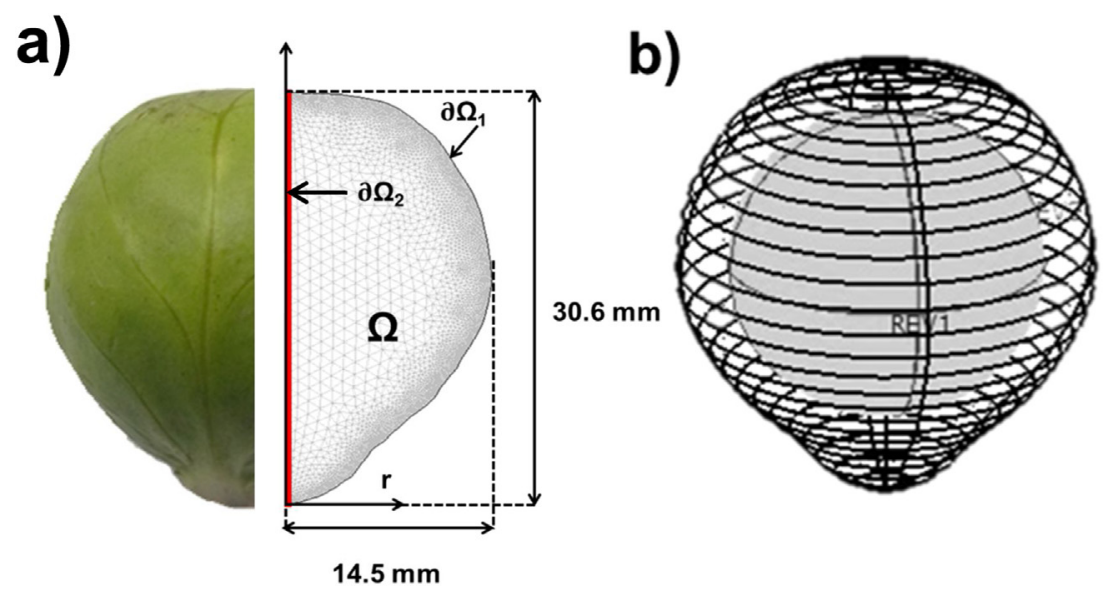

Fig. 1 - (a) Digital photograph of the contour used to generate the vegetable domain (rotating surface that generates the solid of revolution) and the mesh with triangular elements. Dimensions of one of the samples used in the numerical simulations are indicated (b) Inner subdomain defined to simulate the average enzyme activity in the apical (central) region of the vegetable.

$(8.31439 \mathrm{~J} / \mathrm{mol} \mathrm{K}) . \mathrm{T}(\mathrm{r}, \mathrm{z}, \mathrm{t})$ is the temperature $(\mathrm{K})$ as a function of time, at a given position inside the vegetable; this function is calculated using the numerical finite element program for all the time steps and radial and axial positions. By incorporating $\mathrm{T}(\mathrm{r}, \mathrm{z}, \mathrm{t})$ the temperature profile can be associated with an enzyme activity distribution in the Brussels sprout as the thermal treatment evolves.

The average enzyme activity in the whole Brussels sprout was calculated using the following equations:

$\overline{C_{L}}=\frac{\int_{V} C_{L}(r, z, t) d V}{\int_{V} d V}$

$\overline{C_{R}}=\frac{\int_{V} C_{R}(r, z, t) d V}{\int_{V} d V}$

The average overall enzyme activity is given by:

$\overline{\mathrm{C}}=\overline{\mathrm{C}_{\mathrm{R}}}+\overline{\mathrm{C}_{\mathrm{L}}}$

by applying Eqs. (12)-(13) the average enzyme activity for the heat labile and heat resistant fractions were calculated at any time during the precooking stage. All the integrals were calculated numerically; time discretization was implemented using trapezoidal rule; for the volume integrals the quadrature for the standard triangular elements was used (Hughes, 1987)

\subsubsection{Freezing stage}

During the phase change transition in the freezing process the thermo-physical properties are strongly dependent on temperature. This constitutes a highly non-linear mathematical problem. The heat conduction equation in Cartesian coordinates with phase change transition can be written as follows:

$\rho(\mathrm{T}) \mathrm{C}_{\mathrm{p}}(\mathrm{T}) \frac{\partial \mathrm{T}}{\partial \mathrm{t}} \mathrm{r}=\frac{\partial}{\partial \mathrm{r}}\left(\mathrm{k}(\mathrm{T}) \mathrm{r} \frac{\partial \mathrm{T}}{\partial \mathrm{r}}\right)+\frac{\partial}{\partial \mathrm{z}}\left(\mathrm{k}(\mathrm{T}) \mathrm{r} \frac{\partial \mathrm{T}}{\partial \mathrm{z}}\right) \quad$ in $\Omega$

$\mathrm{k}(\mathrm{T})$ is the thermal conductivity, $\mathrm{C}_{\mathrm{p}}(\mathrm{T})$ the apparent specific heat, and $\rho(T)$ the density (Carslaw and Jaeger, 1959). The boundary and initial conditions are:

$\left(\frac{\partial \mathrm{T}}{\partial \mathrm{z}} \cdot \mathrm{n}_{\mathrm{z}}+\frac{\partial \mathrm{T}}{\partial \mathrm{r}} \cdot \mathrm{n}_{\mathrm{r}}\right) \mathrm{k}=\mathrm{h}\left(\mathrm{T}_{\text {ext }}-\mathrm{T}\right) \quad \mathrm{t} \geq 0 \quad$ in $\partial \Omega_{1}$ $\left(\frac{\partial T}{\partial z} \cdot n_{z}+\frac{\partial T}{\partial r} \cdot n_{r}\right) k(T)=0 \quad t \geq 0 \quad$ in $\partial \Omega_{2}$

$\mathrm{T}=\mathrm{T}_{0} \quad \mathrm{t}=0 \quad$ in $\Omega$

where $n_{r}$ and $n_{z}$ are the normal unit vector components in cylindrical coordinates, $h$ in this case corresponds to the surface heat transfer coefficient of the tunnel freezer.

By performing the following change of variables:

$\mathrm{H}(\mathrm{T})=\int_{\mathrm{T}^{*}}^{\mathrm{T}} \rho(\mathrm{T}) \cdot \mathrm{C}_{\mathrm{p}}(\mathrm{T}) \mathrm{dT}$

$E(T)=\int_{T^{*}}^{T} k(T) d T$

where $\mathrm{H}$ is defined as the volumetric specific enthalpy (Comini et al., 1974), E is the Kirchhoff function that represents the thermal conductivity integral (Comini et al., 1974; Fikiin, 1996), and $\mathrm{T}^{*}$ is a reference temperature that corresponds to a zero value of $\mathrm{H}$ and $\mathrm{E}$. These functions are monotonic increasing and continuous because $\mathrm{C}_{\mathrm{p}}, \mathrm{k}$, and $\rho$ are positive and bounded. Consequently, there exists a one to one mapping between the enthalpy/Kirchhoff values and the temperature variable.

By combining Eq. (15), Eq. (19) and Eq. (20), and the initial and boundary conditions represented by Eqs. (16)-(18) the following equations were obtained:

$\frac{\mathrm{dH}}{\mathrm{dt}}=\nabla^{2} \mathrm{E}$

With initial and boundary conditions as follows:

$\mathrm{H}=\mathrm{H}_{0} \quad$ in $\Omega \quad$ a $\mathrm{t}=0$

$-(\nabla \mathrm{E} \cdot \mathrm{n})=\mathrm{h}\left(\mathrm{T}-\mathrm{T}_{\text {ext }}\right) \quad$ in $\partial \Omega_{1} \quad$ a $\mathrm{t}>0$

$-\nabla \mathrm{E} \cdot \mathrm{n}=0 \quad$ in $\partial \Omega_{2} \quad$ a $\mathrm{t}>0$

Applying the finite element technique the following system of ordinary differential equations was solved:

$C G \cdot \frac{d H}{d t}+F G \cdot T(H)+K G \cdot E(H)=m$ 
where:

$\mathrm{CG}=\sum_{\mathrm{e}=1}^{\mathrm{ne}} \int_{\Omega_{\mathrm{e}}}\left(\mathrm{N}^{\mathrm{T}} \mathrm{rN}\right) \mathrm{d} \Omega_{\mathrm{e}}$ is the global capacitance matrix.

$\mathrm{KG}=\sum_{\mathrm{e}=1}^{\mathrm{ne}} \int_{\Omega_{\mathrm{e}}}\left(\mathrm{B}^{\mathrm{T}} \mathrm{rB}\right) \mathrm{d} \Omega_{\mathrm{e}}$ is the global conductive matrix. $\mathrm{FG}=\sum_{\mathrm{s}=1}^{\mathrm{ns}} \int_{\Omega_{\mathrm{s}}}\left(\mathrm{N}^{\mathrm{T}} \mathrm{hrN}\right) \mathrm{d} \delta \Omega_{\mathrm{s}}$ is the global convection matrix.

$\mathrm{m}=\sum_{\mathrm{s}=1}^{\mathrm{ns}} \int_{\partial \Omega_{\mathrm{s}}}\left(\mathrm{N}^{\mathrm{T}} \mathrm{hrT} \mathrm{T}_{\text {ext }}\right) \mathrm{d} \delta \Omega_{\mathrm{s}}$ is the global thermal load vector.

$\mathrm{H}, \mathrm{E}$, and $\mathrm{T}$ are the nodal values of enthalpy, the Kirchhoff function, and temperature, respectively. $\mathrm{N}$ is the vector of dimensions $[1 \times 4]$ containing the shape functions $(\mathrm{Nj})$ with $j=1-4$ for the reference tetrahedron element, $\mathrm{Nt}$ is the transpose vector (dimension $4 \times 1$ ), e is the total number of elements, e1 is the number of boundary elements, $\Omega_{\mathrm{e}}$ is the integration domain, $\partial \Omega_{\mathrm{s}}$ is the boundary integration domain. The matrix $B$ (dimension $3 \times 4$ ) is defined as follows:

$B=\left[\begin{array}{ccc}N_{1 r} & N_{2 r} & N_{3 r} \\ N_{1 z} & N_{2 z} & N_{3 z}\end{array}\right]$ where $\quad N_{i r}=\frac{\partial N_{i}}{\partial r}, \quad N_{i z}=\frac{\partial N_{i}}{\partial z} \quad$ for $i=1-3$

This system was solved using the standard Matlab 6.5 routines ODE (Ordinary Differential Equations) which minimizes the computational efforts of the numerical algorithm.

\subsection{Thermo-physical properties of the Brussels sprouts}

The thermophysical properties of the vegetable samples during the precooking stage were considered constant in the temperature range $1-90^{\circ} \mathrm{C}$. The presence of air in the vegetable was considered and the air volume fraction $(\varepsilon)$ was determined. This air fraction was used to evaluate the effective thermal conductivity by using Maxwell equation for heterogeneous systems. Freezing involves the phase change transition of water into ice as time elapses. The dependence of the thermophysical properties. $\mathrm{k}(\mathrm{T}), \rho(\mathrm{T})$ and $\mathrm{C}_{\mathrm{p}}(\mathrm{T})$ are necessary to simulate the heat transfer inside the vegetable as time elapses.

\subsubsection{Density}

The density ( $\rho$ ) of unfrozen Brussels sprouts was determined by measuring the mass using a Mettler Toledo AB-204 (Switzerland) laboratory balance. Afterwards the vegetable was submerged in a laboratory-graduated cylinder filled with water and the displaced volume corresponded to the volume of the solid object. Density was calculated by the relationship mass/volume (in triplicate). Since the vegetable contains air, the sample was wrapped in aluminum foil attached to a sinker in order to fully immerse the object; the volume of the foil and lead were measured for calculation purposes.

In porous materials with porosity $\varepsilon$ (air volume / total volume), the density can be described by the following equation:

$\frac{(1-\varepsilon)}{\rho}=\sum_{\mathrm{i}=1}^{\mathrm{n}} \frac{\mathrm{xi}}{\rho_{\mathrm{i}}}=\frac{1}{\rho_{\mathrm{s}}}$

Where: $\rho$ is the global density of the vegetable containing air, $\rho_{\mathrm{i}}$ is the density of each component $\mathrm{i}$ (water, carbohydrates, ash, protein, and lipids) that constitutes the solid matrix. The density of the solid matrix $\left(\rho_{\mathrm{s}}\right)$ was calculated using the model proposed by Choi and Okos (1986):

$\rho_{\mathrm{S}}(\mathrm{T})=\frac{1}{\sum \frac{\mathrm{x}_{\mathrm{i}}}{\rho_{\mathrm{i}}}}$ where $\rho_{s}(T)$ is the density of the solid as a function of temperature and $\rho_{\mathrm{i}}$ is the density of component, where i corresponds to water, carbohydrates, ash, lipids, or proteins.

The fraction " $\mathrm{x}_{\mathrm{i}}$ " corresponds to the mass fraction of each component. Choi and Okos (1986) proposed the following expressions for the determination of density of each component:

$\rho$ water $=997.18+3.1439 \times 10^{-3} \mathrm{~T}-3.7574 \times 10^{-3} \mathrm{~T}^{2}$

$\rho$ carbohydrates $=1599.1-0.31046 \mathrm{~T}$

$\rho$ protein $=1330-0.5184 \mathrm{~T}$

$\rho$ lipid $=925.59-0.41757 \mathrm{~T}$

$\rho$ ash $=2423.8-0.28063 \mathrm{~T}$

where the $\rho$ are expressed in $\mathrm{kg} / \mathrm{m}^{3} \mathrm{~T}$ in ${ }^{\circ} \mathrm{C}$ in the range -40 and $150^{\circ} \mathrm{C}$.

The porosity $\varepsilon$ of the vegetable was calculated from Eq. (26) by knowing $\rho$ and $\rho_{\mathrm{s}}$ values. The $\rho$ as a function of T in the freezing range temperatures was estimated considering the ice content that is formed as the temperature decreases. The $\rho$ of ice was calculated as follows (Choi and Okos, 1986): $\rho$ ice $=916.89-0.13071 \times 10^{-1} \mathrm{~T}$.

\subsubsection{Specific heat}

Specific heat of Brussels sprouts in the entire range of temperatures (thermal treatment and freezing process) and the latent heat of ice melting were measured by using a Differential Scanning Calorimeter (DSC) model Q100 TA Instruments, (New Castle, Delaware, USA). Samples were enclosed in sealed aluminum pans. An empty pan was used as a reference sample. Pans were heated at $2{ }^{\circ} \mathrm{C} / \mathrm{min}$ from -50 to $100^{\circ} \mathrm{C}$ with isothermal periods at the initial and final temperatures. In order to measure the specific heat three scans were carried out: one for the sample, one for a standard (sapphire), and one for the empty sample pan. In these scans the reference holder contains an empty pan. Distilled water was also scanned using the same program to verify the equipment calibration. The specific heat was calculated following the ASTM E1269-11 (2011) procedure and McNaughton and Mortimer (1975) recommendations.

The latent heat of melting $\left(\Delta \mathrm{H}_{\mathrm{m}}\right)$ was determined as indicated by Roos (1986) by integrating the peak of the melting curve; this value was used to estimate the unfrozen water fraction in the food material. The temperature integration limits of the peak were chosen when a clear separation between curve and base line was detected.

Unfrozen water fraction (xb), was considered as the difference between total water content and the amount of frozen water in the deep frozen material. The fraction of frozen water was obtained from the ratio between the latent heat of melting determined for the food material and the heat of melting of pure water.

The ice content as a function temperature (at $\mathrm{T}<\mathrm{T}_{\mathrm{f}}$ ) was estimated using the equation proposed by Miles et al. (1983):

$\mathrm{x}_{\mathrm{h}}=\left(\mathrm{x}_{\mathrm{w}}-\mathrm{x}_{\mathrm{b}}\right)\left(1-\frac{\mathrm{T}_{\mathrm{f}}}{\mathrm{T}}\right)$

where $x_{h}$ is the mass fraction of ice, $T_{f}$ is the initial melting point of the product, $x_{\mathrm{W}}$ is the mass fraction of water in the foodstuff, and $\mathrm{x}_{\mathrm{b}}$ is the mass fraction of bound water.

\subsubsection{Thermal conductivity}

To determine the effective thermal conductivity $(k)$ of the vegetable (heterogeneous system containing air) during precooking stage, Maxwell equation was applied using air as the 
disperse phase in the solid continuous phase (Rahman and Said Al-Saidi, 2009; Pietrak and Wiśniewski, 2015).

$\mathrm{k}=\mathrm{kc}\left(\frac{2 \mathrm{kc}+\mathrm{kd}-2 \varepsilon(\mathrm{kc}-\mathrm{kd})}{2 \mathrm{kc}+\mathrm{kd}+\varepsilon(\mathrm{kc}-\mathrm{kd})}\right)$

where kc corresponds to the thermal conductivity of the continuous phase (solid matrix), $\mathrm{kd}$ is the thermal conductivity of the disperse phase (air) and $\varepsilon$ the porosity. The thermal conductivity of the solid matrix (continuous phase) kc of the Brussels sprout was estimated using the following equation (Choi and Okos, 1986):

$k c(T)=\sum x_{i}^{v} \cdot k_{i}(T)$

where: $\mathrm{k}_{\mathrm{i}}$ is the thermal conductivity of component $\mathrm{i}$ which corresponds to the proximate composition of the vegetable (water, carbohydrates, ash, protein, and lipids); $\mathrm{x}_{\mathrm{i}}^{\mathrm{v}}$ corresponds to the volume fraction of each component. In order to calculate the $\mathrm{k}$ of each component the following equations dependent on the temperature $\mathrm{T}\left({ }^{\circ} \mathrm{C}\right)$ were used:

$\mathrm{k}$ water $=0.57109+1.7625 \times 10^{-3} \mathrm{~T}-6.7036 \times 10^{-6} \mathrm{~T}^{2}$

k carbohydrates $=0.20141+1.3874 \times 10^{-3} \mathrm{~T}-4.3312 \times 10^{-6} \mathrm{~T}^{2}$

$\mathrm{k}$ protein $=0.17881+1.1958 \times 10^{-3} \mathrm{~T}-2.7178 \times 10^{-6} \mathrm{~T}^{2}$

$\mathrm{k}$ lipids $=0.18071-2.7604 \times 10^{-3} \mathrm{~T}-1.7749 \times 10^{-7} \mathrm{~T}^{2}$

$\mathrm{k}$ ash $=0.32961+1.4011 \times 10^{-3} \mathrm{~T}-2.9069 \times 10^{-6} \mathrm{~T}^{2}$

The conductivity as a function of temperature during the freezing stage was estimated considering the ice that is formed as temperature decreases. The conductivity of ice as a function of temperature was determined as follows (Choi and Okos, 1986): kice $=2.2196-6.2489 \times 10^{-3} \mathrm{~T}+1.0154 \times 10^{-4} \mathrm{~T}^{2}$

\subsection{Heat transfer coefficients $(h)$}

\subsubsection{Precooking stage: Thermal treatment and cooling in} ice-water bath

To estimate the heat transfer coefficient, an aluminum spherical object was built using similar dimensions as the Brussels sprouts (Radius $=0.025 \mathrm{~m}$ ) and immersed in the same water bath, used for the experiments with the vegetables (temperature range: $80-90^{\circ} \mathrm{C}$ ). A thermocouple was inserted at the center of object to sense the time-temperature history during the thermal treatment in the stirred thermostatic bath and the ice-water bath. The following thermo-physical properties of aluminum were considered: $\mathrm{k}=178.35 \mathrm{~W} / \mathrm{m} \mathrm{K}$, $\rho=2700 \mathrm{~kg} / \mathrm{m}^{3}, C_{p}=908.53 \mathrm{~J} / \mathrm{kgK}$. The lumped heat transfer method was applied based on the resolution of the following ordinary differential equation, which assures an almost instantaneous uniform temperature profile due to the high thermal conductivity of the metal:

$\rho \mathrm{C}_{\mathrm{p}} \mathrm{V} \frac{\mathrm{dT}}{\mathrm{dt}}=\mathrm{hA}\left(\mathrm{Ts}-\mathrm{T}_{\infty}\right)$

where: $\rho$ is the density, $C_{p}$ the specific heat, $V$ the volume, $A$ the surface of the metal sphere. Ts is the temperature of the solid and $\mathrm{T}_{\infty}$ the external temperature of the bath (stirred hot water or water-ice bath).

The analytical solution of Eq. (31) (Sablani, 2009) is as follows:

$\frac{\mathrm{T}-\mathrm{T}_{\infty}}{\mathrm{Ti}-\mathrm{T}_{\infty}}=\exp \frac{-\mathrm{hAt}}{\rho \mathrm{V} \mathrm{C}_{\mathrm{p}}}$ where Ti is the initial temperature of the sphere. After applying the natural logarithm of the experimental dimensionless temperature a linear regression as a function of time allowed to obtain the $h$ value of the system from the slope of the straight line.

Moreover, the $\mathrm{h}$ values were calculated using forced convection literature correlations for spheres during the thermal treatment. The following dimensionless parameters were estimated:

Reynolds : Re $=\frac{\rho \mathrm{vD}}{\mu}$

Nusselt : $\mathrm{Nu}=\frac{\mathrm{hD}}{\mathrm{k}}$

Prandtl : $\operatorname{Pr}=\frac{\mathrm{C}_{\mathrm{p}} \mu}{\mathrm{k}}$

where $\mathrm{D}=$ diameter $(\mathrm{m}) ; \mathrm{k}=$ thermal conductivity of the external fluid (water) (W/m K); $\rho=$ density $\left(\mathrm{Kg} / \mathrm{m}^{3}\right) ; \mathrm{v}=$ fluid velocity $(\mathrm{m} / \mathrm{s}) ; \mu=$ viscosity $(\mathrm{Kg} / \mathrm{m} \mathrm{s}) ; \mathrm{C}_{\mathrm{p}}=$ specific heat $(\mathrm{J} / \mathrm{Kg} \mathrm{K})$. For the cooling stage, natural convection literature correlations were used where the Nusselt number depends on the Grashof (Gr) and Prandtl numbers:

$\mathrm{Gr}=\frac{\mathrm{D}^{3} \rho^{2} \mathrm{~g} \beta \Delta \mathrm{T}}{\mu^{2}}$

where $\beta=$ is the volumetric expansion coefficient $\left(\mathrm{K}^{-1}\right)$

\subsubsection{Freezing stage}

In order to estimate the $h$ value $\left(\mathrm{W} / \mathrm{m}^{2} \mathrm{~K}\right)$ in a tunnel freezer the correlation proposed by Earle (1988) was used, in which the measurement of the cooling air velocity is required. For air velocities $\mathrm{v}<5 \mathrm{~m} / \mathrm{s}$ the equation is:

$h=5.7+3.9 v$

where $\mathrm{v}$ is the air velocity in $\mathrm{m} / \mathrm{s}$. The air velocity of the cooling air was measured using a hot wire anemometer (TSI model 1650). The tunnel freezer used in the experiments was pilot-scale.

\subsection{Initial freezing temperature}

The initial freezing temperature $\mathrm{Tf}$ of the vegetable was experimentally determined from the freezing curves. Tf was measured by using thermocouples inserted at the core of the vegetables by applying the tangent method (Fennema et al., 1973).

\subsection{Enzyme activity and quality attributes of Brussels sprouts during frozen storage}

\subsubsection{Enzyme activity}

The enzyme activity (EA) of POD after the pre-cooking and cooling stage (PC; samples), and in precooked, frozen and stored samples (PCFS) was measured at the apical zone of the Brussels sprout. This zone corresponds to an inner spherical sample of the vegetable (Fig. 1b).The \%EA was experimentally measured according to the technique described in Section 2.3 and calculated as the ratio between the EA of the sample submitted to a specific thermal processing time and that of the raw sample. The EA was related to the quality attributes such as color, texture, and ascorbic acid content. 


\subsubsection{Texture}

The texture was evaluated by a puncture test performed using a texturometer TA-XT2i (Stable Micro Systems Ltd., Godalming, Surrey, UK). The test was carried out using a $2 \mathrm{~mm}$ diameter stainless steel needle probe $(\mathrm{P} / 2)$, with a velocity of $0.5 \mathrm{~mm} \mathrm{~s}^{-1}$ and the puncture reached up to $50 \%$ of the total height of the sample. From the force deformation curve the following parameters were obtained: (i) maximum puncture force in $\mathrm{N}(\mathrm{Fm})$ which corresponds to the first peak and it is related to sample firmness (Olivera et al., 2008), (ii) the slope of force-deformation curve for the processed sample which represents the sample stiffness in $\mathrm{N} / \mathrm{mm}$ (S) (Nguyen et al., 2010). Textural measurements were performed using six replicates to minimize inherent sample-to-sample biological variations.

The determinations were expressed as relative values (\%) calculated as the ratio between texture parameters (Fm and S) of PC and PCFS samples with respect to the raw vegetable.

\subsubsection{Color}

The surface color of Brussels sprouts at the core was determined in PC and PCFS samples. The change of color was determined using a Minolta colorimeter CR 400 Series (Konica, Osaka,Japan). The CIEL*a*b* scale was used to analyze of results of lightness $\left(\mathrm{L}^{*}\right)$ and chromaticity parameters: change of the red-green ( $a^{*}$ parameter) and yellow-blue $\left(b^{*}\right.$ parameter). These results were used to determine the Browning Index (\%BI) according to Eqs. 37 and 38, which represents the purity of brown color.

$\% \mathrm{BI}=\frac{[100(\mathrm{x}-0.31)]}{0.172}$

where

$x=\frac{\left(a^{*}+1.75 L^{*}\right)}{\left(5.645 L^{*}+a^{*}-3.012 b^{*}\right)}$

\subsubsection{Ascorbic acid}

Ascorbic Acid (AA) content of fresh vegetables, after the precooking stage (PC samples), and after frozen storage (PCFS samples) were measured at the apical zone, to evaluate the effect of processing conditions on the AA loss. The AA was determined using liquid chromatographic method in a HPLC Waters equipment (Waters, Milford, MA, USA) Waters 1525 Binary HPLC Pump; Detector UV-Waters 2998 fitted with a photo diode array detector and a RP-C18 column $4.6 \times 150 \mathrm{~mm}$, $5 \mu \mathrm{m}$ (Waters, Milford, MA, USA). This determination consisted of an isocratic elution procedure with UV-vis detection at $245 \mathrm{~nm}$. The samples were grounded taking $0.6 \mathrm{~g}$ and mixed with $2.5 \mathrm{~mL}$ of an aqueous solution containing $5 \mathrm{~g} / 100 \mathrm{~mL}$ metaphosphoric acid (Sigma Aldrich, USA) during $15 \mathrm{~min}$ and later centrifuged for $10 \mathrm{~min}$ at $2000 \mathrm{rpm}$ in centrifuge Rolco CM 2036 (Rolco, Argentina). Supernatants were collected and filtered through a $0.45-\mu \mathrm{m}$ Millipore filter (Millipore Corporation, Billerica, MA, USA). The extracts were stored at $4{ }^{\circ} \mathrm{C}$ until use.

The employed mobile phase was $0.5 \mathrm{~g} / 100 \mathrm{~mL}$ of metaphosphoric acid /acetonitrile (93:7) (Nojavan et al., 2008). A standard ascorbic acid (Sigma Aldrich, USA) solution was used for identification and quantification. An aliquot $(20 \mu \mathrm{L})$ of the extract was used for HPLC analysis, the chromatograms were analyzed using the software Peakfit v.4. 12.00 (SeaSolve Software Inc, Framningham, MA, USA). The reported results correspond to the mean of 2 determinations for each sample. The residual $\mathrm{AA}$ was determined as $\mathrm{AA} / \mathrm{AA}_{\mathrm{O}}$, where $\mathrm{AA}$ is the ascorbic acid in precooked vegetables after frozen storage (PCFS) and $\mathrm{AA}_{0}$ the initial AA content in the fresh vegetable.

\subsection{Sensory analysis}

A sensory evaluation with a panel of 30 consumers was carried out using a 9 point hedonic scale to determine the degree of liking of the final product (Peryam and Girardot, 1952). The acceptability test was applied and the scale assigned one for "dislike extremely" and nine for "like extremely". Analysis of variance followed by comparisons of means for more than two products (Lawless and Heymann, 2010) was applied to analyze the information. Sensory analysis was based on the evaluation of four samples: F(cooked fresh vegetable, control sample), PCFS (samples precooked during 3, 6 or $10 \mathrm{~min}$ at $90^{\circ} \mathrm{C}$, frozen and stored 4 months at $-20^{\circ} \mathrm{C}$ ). The sample $\mathrm{F}$ consisted in the fresh vegetable which was washed, rinsed and cooked in water during $10 \mathrm{~min}$ at $90^{\circ} \mathrm{C}$ before consumption. The frozen stored samples (PCFS) were heated similarly at $90^{\circ} \mathrm{C}$ during $3 \mathrm{~min}$. before consumption. All the samples were analyzed for their global acceptability, evaluating the following attributes: general acceptability, interior color, texture and aroma. Samples were presented in disposable trays that contained the three samples.

\subsection{Statistical analysis}

In order to estimate the goodness of fit of the numerical simulation model, experimental and predicted temperatures were considered in each stage (pre-cooking and freezing) and the root mean square error (RMSE) was determined as follows:

RMSE $=\sqrt{\frac{\sum\left(\mathrm{T}_{\text {exp }}-\mathrm{T}_{\text {pred }}\right)^{2}}{\mathrm{~N}}}$

The software Origin Pro 8 (Origin Lab Corporation, Northampon, Ma., U.S.A.) was used for analysis of variance (ANOVA). The analyses were carried out to assess significant differences between the samples; means were compared by a Fisher LSD test using a 95\% confidence level (significant difference, $\mathrm{P} \leq 0.05)$.

\section{Results and discussion}

\subsection{Thermo-physical properties and heat transfer coefficients during the precooking stage}

The average proximal composition values of the vegetable and their Standard Deviation (between parentheses) were: 83.54\% $(\mathrm{SD}=0.55)$ moisture, $3.20 \%(\mathrm{SD}=0.09)$ protein, $0.36 \%(\mathrm{SD}=0.02)$ fat, $1.19 \%(\mathrm{SD}=0.02)$ ash, and $11.74 \%$ carbohydrate calculated by difference.

The experimental density value of the Brussels sprouts was $\rho=880 \mathrm{~kg} / \mathrm{m}^{3} \quad(\mathrm{SD}=12)$. The density of the solid matrix was calculated based on the proximal composition using Eq. (27) being $1050 \mathrm{~kg} / \mathrm{m}^{3}$. By applying Eq. (26) a porosity $(\varepsilon)$ of $16 \%$ was obtained.

The thermal conductivity of the solid continuous matrix (without air) $\mathrm{kc}=0.55 \mathrm{~W} / \mathrm{m} \mathrm{K}$ was estimated using Eq. (30). Using the Maxwell equation (Eq. 29) with a value of porosity $\varepsilon=16 \%$, and a thermal conductivity of air at $50^{\circ} \mathrm{C}$ of $0.02735 \mathrm{~W} / \mathrm{m} \mathrm{K}$, a value of $\mathrm{k}=0.50 \mathrm{~W} / \mathrm{mK}$ was obtained for the vegetable sample. An average value of the specific heat, 
$\mathrm{C}_{\mathrm{p}}=3.86 \times 10^{3} \mathrm{~J} / \mathrm{kg} \mathrm{K}$ was obtained by DSC for the temperature range $1-100^{\circ} \mathrm{C}$; in this temperature range $C_{p}$ is almost constant.

The heat transfer coefficients (h) in both stages: (a) thermal treatment in a stirred thermostatic bath (forced convection condition) and (b) cooling in an ice-water bath (natural convection condition) were determined using an aluminum sphere. In the case of stage (a), the average $h$ value was $2262 \mathrm{~W} / \mathrm{m}^{2} \mathrm{~K}$ $(\mathrm{SD}=285.02)$. Additionally, literature correlations were used to compare these $\mathrm{h}$ values (Earle, 1988; Nesvadba, 2008). The equation used during the thermal treatment for spheres immersed in a fluid under forced convection conditions was:

$\mathrm{Nu}=2+0.6 \operatorname{Re}^{1 / 2} \operatorname{Pr}^{1 / 3}$

The aluminum sphere $(D=0.05 \mathrm{~m})$ had an initial temperature of $20^{\circ} \mathrm{C}$ and the hot water $90^{\circ} \mathrm{C}$, therefore the film temperature was $\mathrm{T}_{\mathrm{f}}=55^{\circ} \mathrm{C}$; the properties of water were considered at $\mathrm{T}_{\mathrm{f}}$ (Dinçer and Zamfirescu, 2015). The Prandtl number at a temperature $\mathrm{T}_{\mathrm{f}}$ calculated by using Eq. (35) was $\operatorname{Pr}=3.4$. The velocity of the water in the stirred bath was $35 \mathrm{~cm} / \mathrm{s}(\mathrm{SD}=4 \mathrm{~cm} / \mathrm{s})$. An average Re number was calculated by Eq. (33) obtaining $\mathrm{Re}=3.74 \times 10^{4}$. Finally the $\mathrm{Nu}$ number was calculated using Eq. (34), resulting in 176.92 and $\mathrm{h}=2300 \mathrm{~W} / \mathrm{m}^{2} \mathrm{~K}$. Applying the correlation Eq. (41) for Brussels sprouts with an average diameter of $0.036 \mathrm{~m}$ and using literature thermo-physical properties of water the $h$ value was $\mathrm{h}=2414 \mathrm{~W} / \mathrm{m}^{2} \mathrm{~K}$.

In the case of cooling (the metal sphere was immersed in the ice-water bath) the average $\mathrm{h}$ value obtained by using Eq. (32) was $\mathrm{h}=494 \mathrm{~W} / \mathrm{m}^{2} \mathrm{~K}(\mathrm{SD}=50)$. Moreover, a dimensionless correlation for spheres under natural convection conditions was applied:

$\mathrm{Nu}=2+0.6 \mathrm{Gr}^{1 / 4} \operatorname{Pr}^{1 / 3}$

The dimensionless numbers calculated were $\mathrm{Gr}=2.8 \times 10^{6}$; $\mathrm{Pr}=3.55$ and $\mathrm{Nu}=39$, resulting in a value of $\mathrm{h}=500 \mathrm{~W} / \mathrm{m}^{2} \mathrm{~K}$, which is close to that obtained experimentally. Using the dimensions of the Brussels sprouts with the natural convection correlation $(D=0.036 \mathrm{~m})$ the $h$ value obtained was $\mathrm{h}=567 \mathrm{~W} / \mathrm{m}^{2} \mathrm{~K}$ for the ice-water bath.

\subsection{Numerical simulation of thermal histories in the precooking process. Model validation}

The 3D object was built by revolution of the bidimensional domain (Fig.1a,b). A triangular mesh using Lagrange elements of order 2 was applied to discretize the domain. The number of elements that constituted the mesh for the whole vegetable was 4664 with a total number of nodal points of 2437. The apical region was discretized using 1786 elements. The use of finer mesh showed no significant effect on the accuracy of the solution. The time discretization scheme used was a Backward Euler Differentiation (minimum order 1 and maximum order 5) with a tuning step having a maximum of $0.1 \mathrm{~s}$ and a minimum initial starting value of $0.001 \mathrm{~s}$. The absolute and relative tolerances for each integration step were 0.001 and 0.01 , respectively.

Operating conditions were modeled, considering two different $h$ values for heating and cooling. This allowed to obtain the time-temperature profile in the entire domain of the vegetable. Fig.2a) shows one the analyzed cases of the predicted and experimental time-temperature curves during the pre- cooking stage corresponding to a thermocouple position $r=0$, $z=21.3 \mathrm{~mm}$. Vertical dashed line indicates the time when the thermal treatment stopped and the vegetable was cooled in the ice-water bath. In this figure the experimental conditions were: temperature of the stirred thermostatic bath $90^{\circ} \mathrm{C}$, thermal processing time: $6 \mathrm{~min}$; Heat transfer coefficient $\mathrm{h}=2200 \mathrm{~W} / \mathrm{m}^{2} \mathrm{~K}$ for the stirred hot water bath and $\mathrm{h}=580 \mathrm{~W} / \mathrm{m}^{2} \mathrm{~K}$ for the ice-water bath. An excellent agreement can be observed indicating that the program satisfactorily simulates the time temperature curve of the precooking process. For three replicates RMSE calculated were $1.85,2.55$ y $2.33^{\circ} \mathrm{C}$. As can be observed in the thermal history during the cooling stage, the temperature at the analyzed point increased even though the vegetable was submitted to a low external fluid temperature during the cooling stage.

The predicted mean temperature $(\overline{\mathrm{T}})$ of the inner apical zone (interior subdomain) was calculated as follows:

$\overline{\mathrm{T}}=\frac{\int \mathrm{T}(\mathrm{r}, \mathrm{z}, \mathrm{t}) \mathrm{dV}}{\int \mathrm{dV}}$

where $T(r, z, t)$ are the temperatures at each point of the apical zone. Fig. $2 \mathrm{~b}$ shows the mean temperature $\overline{\mathrm{T}}$ (dashed line) obtained by applying Eq. (43).

Fig. $2 \mathrm{c}$ shows the predicted temperature distributions in different sections of the whole vegetable during the thermal treatment in the stirred hot water bath during $6 \mathrm{~min}$ and the subsequent cooling process.

\subsection{Coupling the heat transfer process with enzyme inactivation kinetics and comparison of predicted values with enzyme activity measurements}

During heating and cooling stages enzyme inactivation occurs; this amount of inactivated enzyme should be quantified to avoid overcooking and losses of thermolabile compounds such as ascorbic acid. The enzyme inactivation kinetics was coupled to the main heat transfer program allowing to estimate the residual enzyme activity at each position and time during the process. In order to compare the experimental and predicted enzyme activity of the Brussels sprout at the apical zone, the mean temperature calculated by Eq. (43) was used. The average enzyme activity at the apical zone was calculated in this subdomain as a function of the mean temperature $(\overline{\mathrm{T}})$ during the thermal treatment and cooling stages.

Fig. $2 \mathrm{~b}$ shows the numerical predictions of the average POD enzyme activity and the $\overline{\mathrm{T}}$ vs. time curve obtained for the apical zone. As can be observed during the cooling process the apical region remained at a high temperature for an additional time, increasing the inactivation of POD.

Table 1 shows the effect of thermal treatment times $(3,6$, $10 \mathrm{~min}$ ) on experimental and predicted Enzyme activity (\%EA) of POD in the apical and external regions of the Brussels sprouts.

The enzyme activity (\%EA) measurements required the extraction of POD in a finite volume of vegetable, because it cannot be assigned to a single point such as in the case of temperature.

Therefore the apical zone was defined as the internal sphere in the vegetable where the \%EA was evaluated (Fig. 1b), corresponding the external zone to the outer region. Differences between experimental and predicted values of \%EA can be justified considering two important reasons: i) the reported data of \%EA correspond to volumetric aver- 
a)

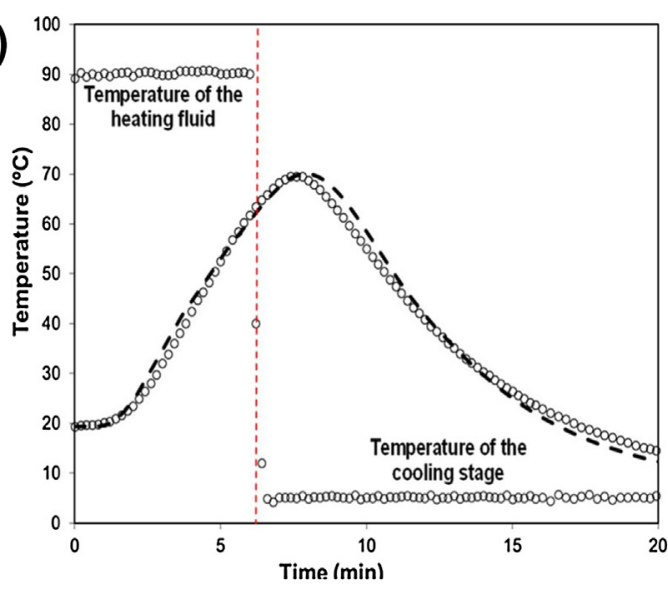

c)
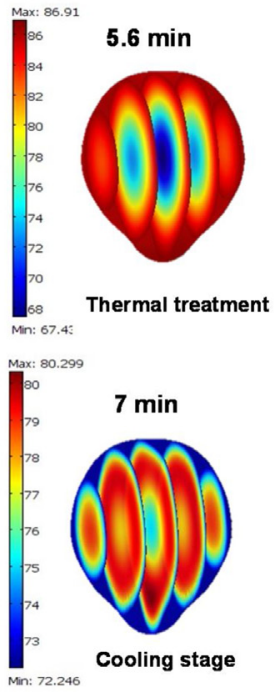
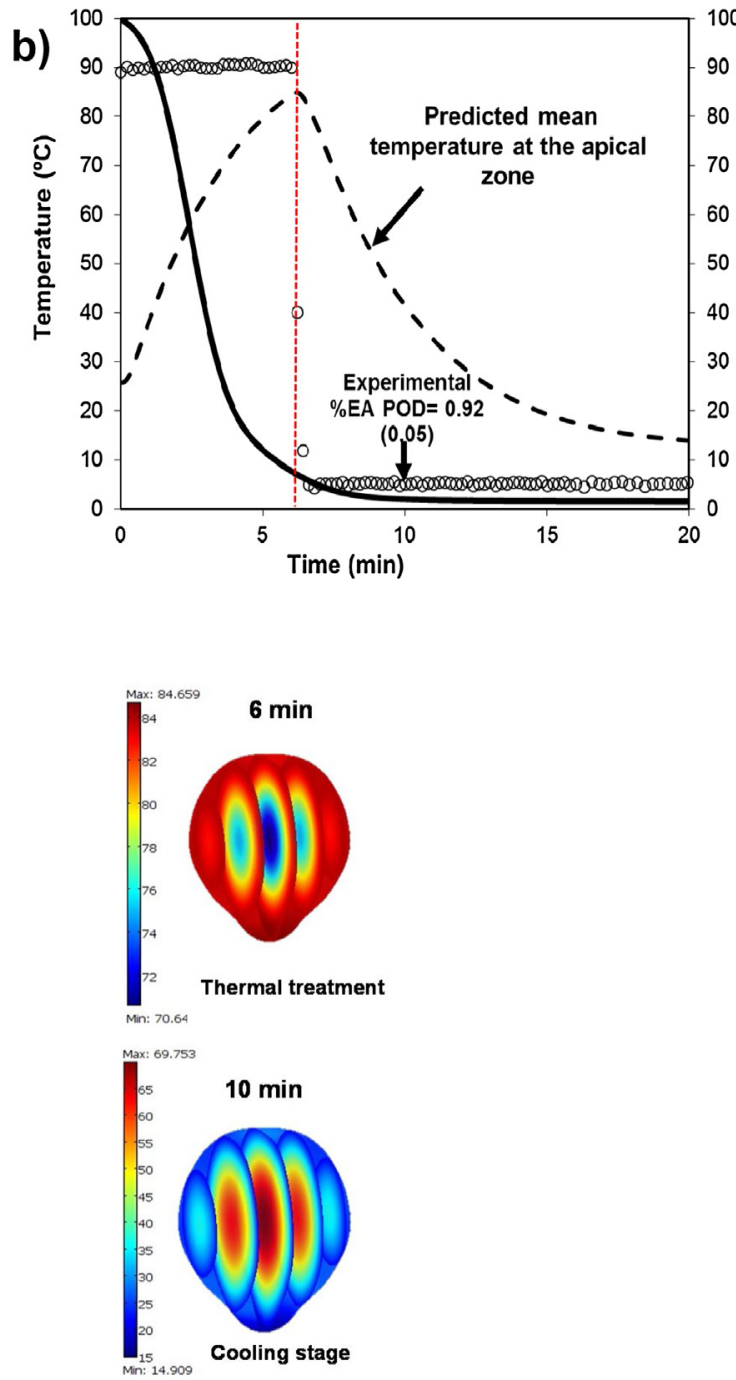

Fig. 2 - (a) Experimental-time temperature measurements (o) and Numerical predictions (- - ) at a particular inner point of the vegetable. Thermocouple position $r=0, z=21.3 \mathrm{~mm}$. during the precooking stage. Vertical dashed line indicates the time when the thermal treatment stops and the vegetable is cooled in the ice-water bath. Conditions: Temperature of the stirred thermostatic bath $90^{\circ} \mathrm{C}$, thermal processing time: $6 \mathrm{~min} ; \mathrm{h}=2200 \mathrm{~W} / \mathrm{m}^{2} \mathrm{~K}$ for the stirred hot water bath and $\mathrm{h}=580 \mathrm{~W} / \mathrm{m}^{2} \mathrm{~K}$ for the ice-water bath.

(b) Numerical predictions as functions of time, at the apical zone. Mean temperature (--) obtained by applying Eq. (43) and Residual POD activity (---) obtained by coupling the enzyme inactivation kinetics with the heat transfer program.

Conditions are the same as described in (a). The arrow indicates experimental enzyme activity measured at the apical region after $10 \min (n=6)$.

(c) Time temperature distribution of the Brussels sprouts at different processing times. The thermal processing time in the hot stirred bath was 6 min.

Table 1 - Experimental and Predicted Enzyme Activity (\%) of POD considering the apical and external regions of the Brussels sprouts. Values between parentheses are standard deviations $(n=6)$.

\begin{tabular}{lllll}
\multirow{2}{*}{$\begin{array}{c}\text { Time } \\
(\mathrm{min})\end{array}$} & \multicolumn{2}{c}{ Apical } & & External \\
\cline { 2 - 3 } & $\begin{array}{l}\text { Experimental } \\
\text { \%EA }\end{array}$ & $\begin{array}{l}\text { Predicted } \\
\text { \%EA }\end{array}$ & Experimental & Predicted \\
\%EA
\end{tabular}

a Data reported in literature by Perez-Calderon et al. (2015). 


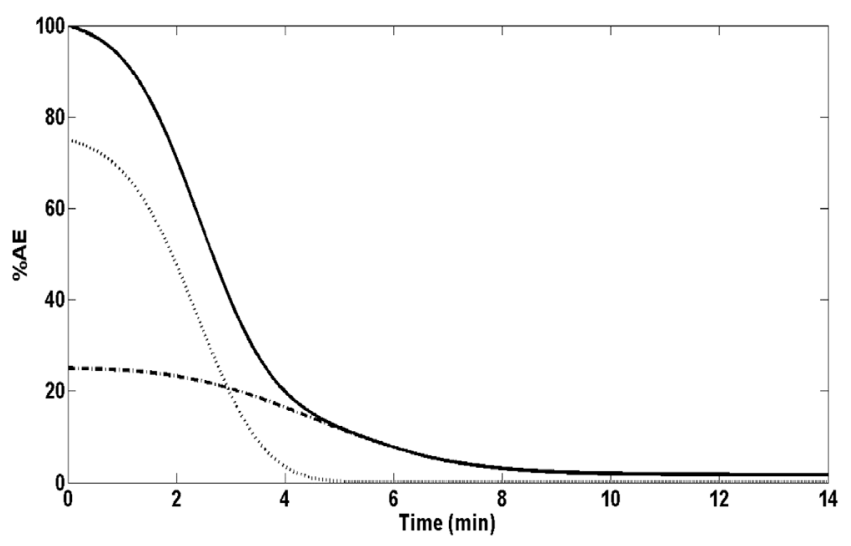

Fig. 3 - \% Total Enzyme activity 0, thermo-labile fraction ('.) and thermo-resistant (- -) for POD.

age values and ii) the biological variability of the tested samples.

Fig. 3 shows the numerical predictions for the enzyme inactivation of the thermo-labile and thermo-resistant isoenzymes within the entire vegetable as a function of time for a bath temperature of $90^{\circ} \mathrm{C}$. From these results, the residual enzyme activity after the precooking process was determined, being this value the initial \% EA of Brussels sprouts for the freezing process.

\subsection{Numerical simulation of the freezing process}

The thermo-physical properties $\mathrm{C}_{\mathrm{p}}$ and $\mathrm{k}$ of the vegetable in the entire range of temperatures are shown in Fig. 4. These data allowed to estimate the Kirchhoff and Enthalpy functions. The initial freezing temperature was $-1{ }^{\circ} \mathrm{C}$, following the procedure reported by Fennema et al. (1973). The bound water fraction in wet basis obtained using the DSC thermogram was $\mathrm{x}_{\mathrm{b}}=0.1843$ ( $\mathrm{g}$ of bound water/g of total mass).

The volumetric specific heat was calculated by multiplying the $\rho(T)$ by the $C_{p}(T)$, and further numerically integrated using Eq. (19) to obtain the enthalpy function $\mathrm{H}$ (T) (Fig. 5a). The same procedure was carried out with $\mathrm{k}(\mathrm{T})$ in order to obtain the Kirchhoff function (E(T)) according to Eq. (20) (Fig. 5b); Fig. 5c) shows the function $\mathrm{E}(\mathrm{H})$.

The surface heat transfer coefficient in the tunnel freezer was in the range $15-20 \mathrm{~W} / \mathrm{m}^{2} \mathrm{~K}$ (the average air flow velocity was $2.5 \mathrm{~m} / \mathrm{s}$ ). For Brussels sprouts an $\mathrm{h}$ value of $19 \mathrm{~W} / \mathrm{m}^{2} \mathrm{~K}$ gave the best fit to the experimental measurements.

In order to validate the model, the experimental timetemperature curves were compared with the numerical predictions (in triplicate). Fig. $5 \mathrm{~d}$ shows the numerical results and experimental measurements indicating the excellent performance of the numerical code to simulate the freezing process. The RMSE calculated was $0.965^{\circ} \mathrm{C}$. Numerical simulation allows to determine time temperature histories and freezing times as a function of initial temperature of the sample, refrigerant fluid temperature and $\mathrm{h}$ values.

\subsection{Quality attributes after thermal treatment and frozen storage}

\subsubsection{Texture analysis}

Maximum force (Fm) and stiffness (S) values for the raw vegetable were $26.80 \mathrm{~N}, 12.18 \mathrm{~N} / \mathrm{mm}$ respectively. Relative texture values with reference to the raw vegetable, considering the tested pre-cooking times, for PC (precooked samples) and PCFS (precooked, frozen and stored samples) are shown in Table 2. Both relative measurements, the percent maximum puncture force $(\% \mathrm{Fm})$ and relative stiffness $(\% \mathrm{~S})$ decreased after each stage of the process for each treatment time $(3,6,10 \mathrm{~min})$ in all the samples. Significant differences are observed among the samples submitted to the tested heating times $(\mathrm{P} \leq 0.05)$. During thermal processing and freezing, a gradual tissue softening was produced and these irreversible changes are caused by tissue fractures and mechanical damage of the cell walls generating water leaching (Kidmose and Martens, 1999; Paciulli et al., 2015).

\subsubsection{Sensory analysis, enzymatic browning and ascorbic} acid content after frozen storage as affected by residual POD enzyme activity

The residual enzyme activity of POD at the apical zone of the Brussels sprouts was determined in PC and PCFS samples; three precooking times at $90^{\circ} \mathrm{C}(3,6,10 \mathrm{~min})$ were evaluated in each case. Fig. 6 a shows the image of the apical region of Brussels sprouts corresponding to: frozen untreated samples (FU) and PCFS that were thermal treated during 3,6 and $10 \mathrm{~min}$

FU and the PCFS samples with an insufficient thermal treatment time ( $3 \mathrm{~min}$ ) (Fig. 6a) showed the formation of a brown color at the center of the vegetable that is not accepted by the consumer; therefore this short thermal treatment was excluded from the sensory analysis.

Experiments carried out with fresh vegetables that were frozen without a precooking stage (FU) showed a 79\% (SD =1.2) increase in their EA\% accompanied with a marked decrease of AA content $(21 \%(S D=5.6))$ after a 4 months storage at $-20^{\circ} \mathrm{C}$; these results showed the fact that enzymes maintain their activity during frozen storage, and a precooking stage is needed in order to adequately store these vegetables.

Figs. $6 \mathrm{~b}$ and $\mathrm{c}$ corresponding to PC samples (unfrozen precooked vegetable) and PCFS samples (precooked samples stored during 4 months at $-20^{\circ} \mathrm{C}$ ) respectively, show the results of Ascorbic acid content (\%AA), Browing index (\%BI), Peroxidase enzyme activity (\%EA POD) at the apical region, as functions of precooking times (3, 6 and $10 \mathrm{~min}$ ).

Fig. $6 \mathrm{~b}$ showed that for the tested precooking times $(3,6$, and $10 \mathrm{~min}$ ) the values of residual POD activity were: $7.3 \%$ $(\mathrm{SD}=0.9), 0.92 \%(\mathrm{SD}=0.05)$ and $0.2 \%(\mathrm{SD}=0.03)$ respectively. These values complied with the conditions of a residual enzyme activity ranging between $7.5-11 \%$ for POD in Brussels sprouts suggested by Williams et al. (1986) in order to obtain a stabilized vegetable with optimum quality (precooked vegetable unfrozen).

However, as can be observed in Fig. 6c for a precooking time of $3 \mathrm{~min}$ the \%EA after frozen storage (sample PCFS) showed a marked increase of POD $(83.5 \%(S D=1.6)$ for the apical region that can be attributed to enzyme reactivation as was reported by Pérez-Calderón et al. (2017). Therefore it can be concluded that a residual \%EA above $5 \%$ led to the reactivation of the enzyme after frozen storage, and the target upper limit of $\% \mathrm{EA}<5$ should be established in order to assure the final quality and nutritional value of the product

This enzyme reactivation (POD) in samples pre-cooked for $3 \mathrm{~min}$, led to a decrease of the AA content (\%AA $=23.2 \%$ $(\mathrm{SD}=2.1))$ after frozen storage 4 months at $-20^{\circ} \mathrm{C}$ (Fig. $6 \mathrm{C}$ ) because the presence of POD could promote the rapid oxidation of AA (Brewer and Begum, 2003). Gökmen (2010) reported that degradation of AA was high in the case of peas that were subjected to insufficient thermal treatment to inactivate 

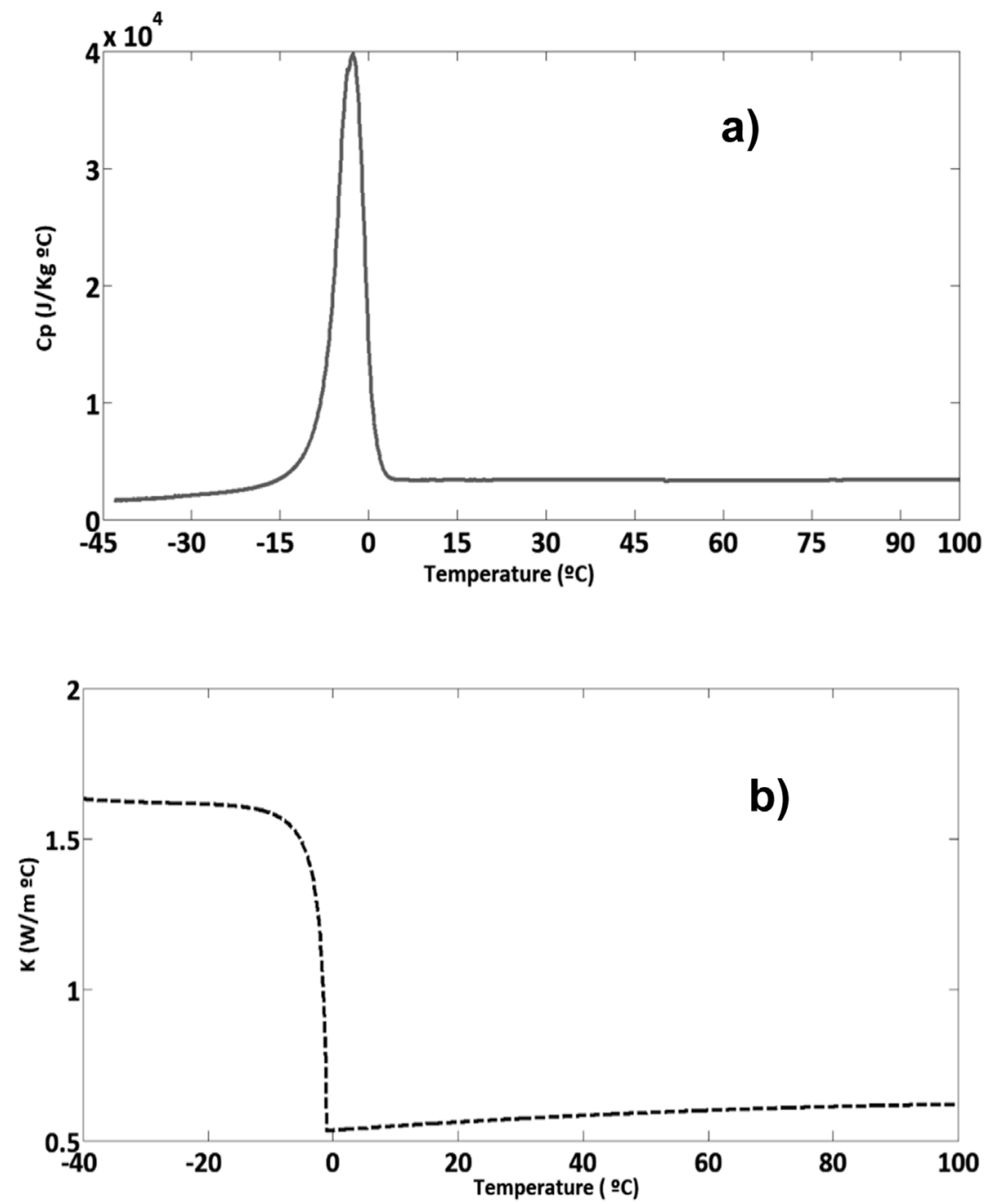

Fig. 4 - Thermo-physical properties of the vegetable as a function of temperature (a) specific heat (obtained by DSC) (b) thermal conductivity.
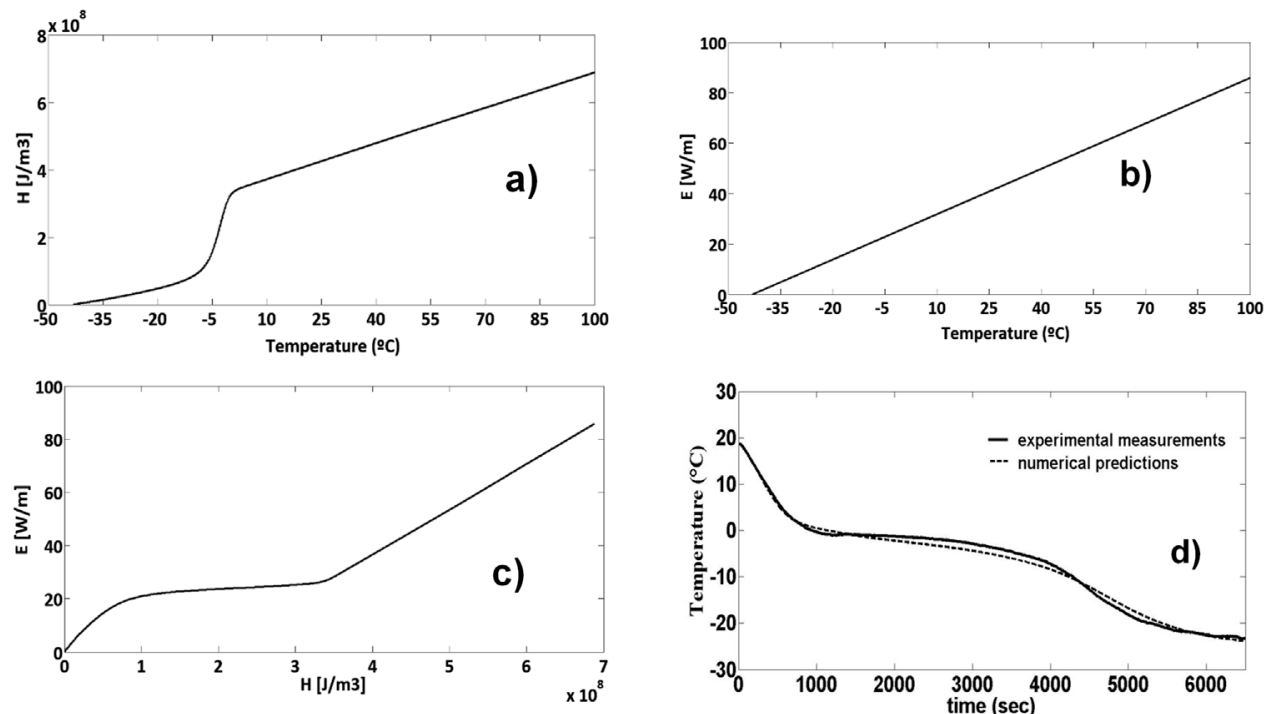

Fig. 5 - Functional relationships used in the finite element formulation, (a) Enthalpy vs. temperature; (b) Kirchhoff function vs. temperature; (c) Kirchhoff function vs. enthalpy. (d) Experimental measurements and numerical predictions of the model during freezing. Thermocouple position $r=6 \mathrm{~mm}, z=23.8 \mathrm{~mm}$. Initial temperature of the vegetable $19.4^{\circ} \mathrm{C}$, air tunnel temperature $-25^{\circ} \mathrm{C}$. 
Table 2 - Effect of pre-cooking times on relative texture parameters with respect to the raw vegetable: Maximum puncture force (\% Fm) and stiffness (\%S) of pre-cooked and cooled samples (PC) and precooked, frozen and stored samples (PCFS) submitted to different precooking times $(3,6,10 \mathrm{~min})$. The values between parentheses correspond to standard deviations, $(n=6)$. Different letters in the same column indicate significant differences between the samples $(P \leq 0.05)$.

Pretreatment heating time $(\mathrm{min})$

PC

\begin{tabular}{ll}
\multicolumn{2}{c}{ PC } \\
\hline$\%$ Fm & $\% S$ \\
\hline $92.5^{\mathrm{a}}(16)$ & $93.4^{\mathrm{a}}(5.5)$ \\
$50.1^{\mathrm{b}}(7.6)$ & $23.8^{\mathrm{b}}(4.2)$ \\
$33.9^{\mathrm{c}}(8.0)$ & $17.2^{\mathrm{c}}(4.5)$
\end{tabular}

PCFS

\begin{tabular}{ll}
\hline$\% \mathrm{Fm}$ & $\% \mathrm{~S}$ \\
\hline $38.6^{\mathrm{C}}(10)$ & $6.9^{\mathrm{a}}(1.2)$ \\
$30.5^{\mathrm{b}}(6.2)$ & $6.4^{\mathrm{b}}(0.8)$ \\
$22.9^{\mathrm{c}}(2.9)$ & $5.1^{\mathrm{c}}(0.4)$
\end{tabular}

a)

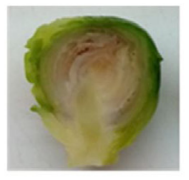

FU

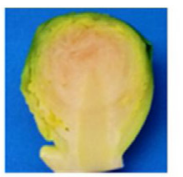

$3 \mathrm{~min}$

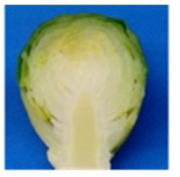

$6 \mathrm{~min}$

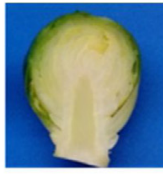

$10 \mathrm{~min}$

\section{PCFS}

b)

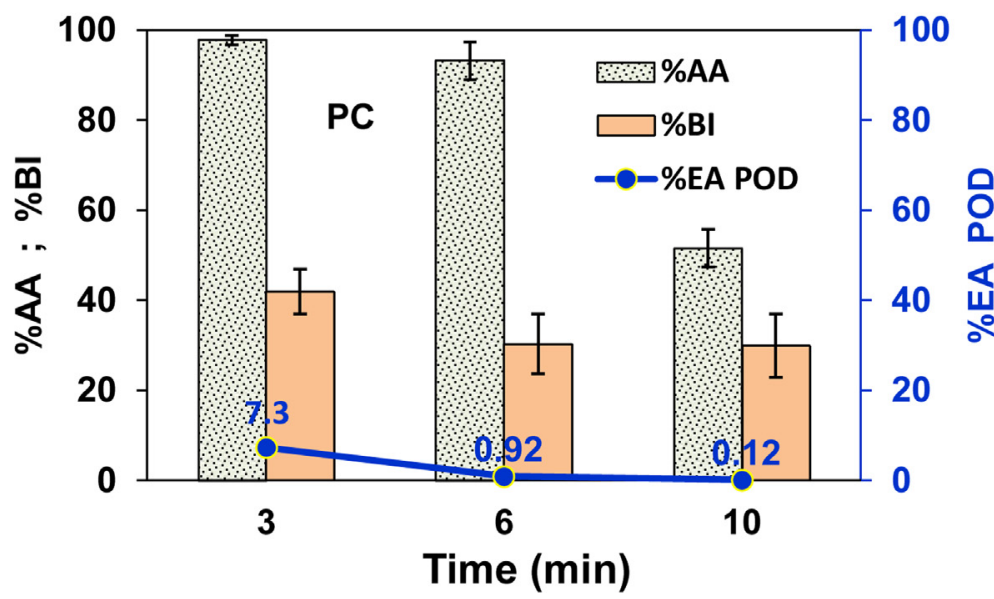

c)

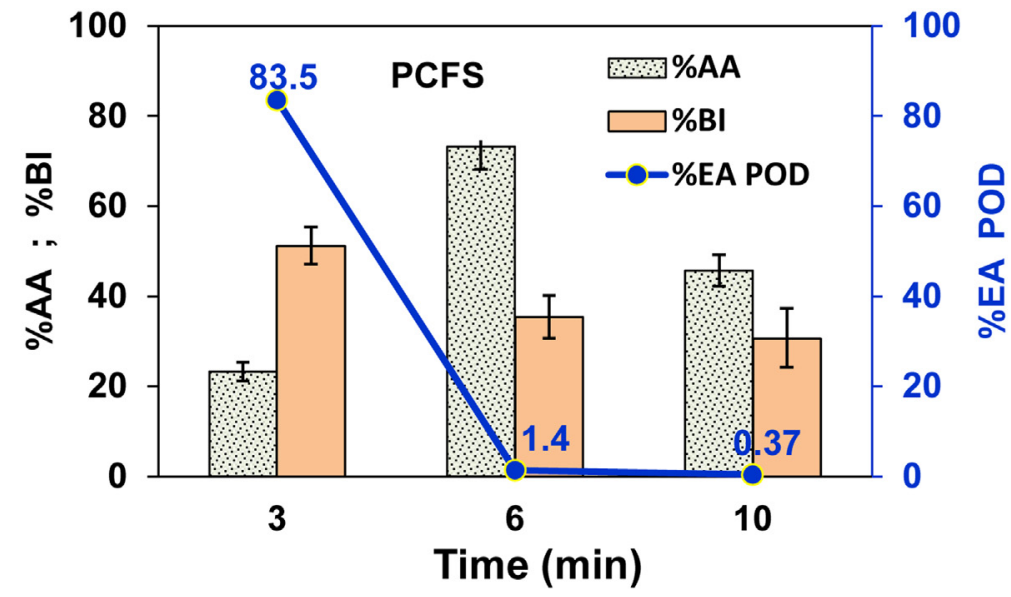

Fig. 6 - (a) Photographs showing the apical zone of Brussels sprouts corresponding to: frozen untreated samples (FU) and precooked samples (PCFS) during 3,6 and $10 \mathrm{~min}$ at $90^{\circ} \mathrm{C}$. All the samples were submitted to a frozen storage of $4 \mathrm{months}$ at $-20^{\circ} \mathrm{C}$. Graphs (b) and (c) corresponding to PC samples (unfrozen precooked vegetable) and PCFS samples (precooked samples stored during 4 months at $-20^{\circ} \mathrm{C}$ ) respectively, show the results of Ascorbic acid content (\%AA),Browing index (\%BI), Peroxidase enzyme activity (\%EA POD) at the apical region, as functions of precooking times (3, 6 and $10 \mathrm{~min})$. Error bars indicate standard deviation of the average values. 
enzymes, due to the action of oxido-reductases enzymes such as ascorbic oxidase and POD.

AA is thermolabile, and has antioxidant activity; it is an important biocomponent in sensory and nutritional attributes, therefore it is used as a quality parameter. Its concentration decreases during frozen storage, depending on conditions, such as temperature, oxygen content, light and time (Torregrosa Verdú, 2006).

The \%BI for a 3 min thermal treatment correlates with the $P O D$ reactivation showing an increase of $10 \%$ in this parameter after frozen storage (Fig. 6c). For PCFS samples with heating times of 6 and $10 \mathrm{~min}$, values of \%BI were acceptable and no significant differences were found $(\mathrm{P} \geq 0.05)$; however for 10 min treatment \%AA was markedly lower compared to a 6 min processing time. Murcia et al. (2000) reported a drastic decrease in the AA content for broccoli by increasing the exposure time in the pre-cooking treatment. After $15 \mathrm{~min}$ at $90^{\circ} \mathrm{C}$, AA losses comprised between 40 and $50 \%$. One of the causes of AA decrease is the breakdown of plant tissues by the action of heating in water, generating changes in cells permeability and leaching of this compound (Olivera et al., 2008).

Gonçalves et al. (2011) studied the degradation kinetics of AA in broccoli, and they observed that under isothermal storage conditions $\left(-18^{\circ} \mathrm{C}\right)$ the most drastic changes in AA content occurred during the first 55 days. Similar results were reported for peas, spinach, green beans and okras (Giannakourou and Taoukis, 2003). González-Hidalgo et al. (2018) found that for broccoli pre-cooked for $2 \mathrm{~min}$ at $97^{\circ} \mathrm{C}$ and frozen at $-20^{\circ} \mathrm{C}$, the percentage of AA after frozen storage was around $69 \%$.

Comparing the results of the tested precooking times it can be inferred that the optimal heating time is 6 min since it maintained the highest AA value in the apical zone of the vegetable after frozen storage(AA $=73.1 \%)$ with an acceptable browning index $\mathrm{BI}=35 \%(\mathrm{SD}=4.70)$.

The sensory analysis included the evaluation of the general acceptability; the obtained scores of the precooked, frozen and stored vegetables were: $6.6(\mathrm{SD}=1.1)$, for PCSF samples heated during $6 \mathrm{~min}$, and $6.9(\mathrm{SD}=2.4)$ for those heated during $10 \mathrm{~min}$, in comparison to the cooked fresh vegetable F (Score 6.7, $(\mathrm{SD}=2.1))$. The sensory analysis indicated that consumers did not detect differences between the precooked frozen vegetable and the fresh one.

\section{Conclusions}

The finite element method was applied to simulate heat transfer phenomena that are involved during the production of precooked frozen Brussels sprouts (heating, cooling and freezing). The coupling of subroutines that describe the inactivation of peroxidase in these vegetables was carried out during the precooking process which involves the thermal treatment and a cooling stage. The software Comsol Multiphysics $3.4 \mathrm{~b}$ was implemented with specific Matlab subroutines in order to determine the enzyme activity of the thermolabile and thermo-resistant fractions of POD at each position and time during the process, considering the irregular shape of the vegetable.

All the numerical results were tested against experimental time-temperature curves and enzyme activity of POD in order to validate the model; a good agreement was obtained and the solution of the numerical code showed the temperature distribution and POD activity at the apical and external zones.
By using Enthalpy and Kirchhoff formulations in the partial differential heat transfer equation, the finite element numerical program was able to predict the time-temperature curve during the freezing process and to calculate freezing times. This change in the variables allowed to solve a complex nonlinear problem involving phase change with a marked dependence of the properties with temperature and strong convergence difficulties. The thermo-physical properties and their temperature dependence were measured and considered in the numerical code.

Quality parameters of the frozen vegetable such as Browing Index, textural properties, residual POD activity and ascorbic acid content were analyzed for several precooking times (3, 6 and $10 \mathrm{~min}$ ) after freezing and storage during 4 months period at $-20^{\circ} \mathrm{C}$. The sensory analysis confirmed the general acceptability of the precooked frozen product.

From the evaluation of the quality parameters it could be concluded that the optimal processing time which maintained the highest ascorbic acid content with an acceptable browning index in the apical zone of the vegetable was $6 \mathrm{~min}$. It was demonstrated that a short heating time (i.e $3 \mathrm{~min}$ ) was insufficient to avoid POD reactivation after frozen storage.

These results are useful for food processors since the numerical programs applied can be used to predict the optimum processing times in order to obtain a high quality and nutritious vegetables. This work contributes to the knowledge of industrial processing times in the precooked frozen vegetable industry.

\section{Acknowledgments}

The authors gratefully acknowledge the financial support from Universidad Nacional de La Plata (UNLP), Consejo Nacional de Investigaciones Científicas y Técnicas (CONICET), Comisión de Investigaciones Científicas (CIC) de la Provincia de Buenos Aires, ANPCYT and (Agencia Nacional de Promoción Científica y Tecnológica).

\section{References}

AOAC, 2010. Official Methods of Analysis, 16h ed, Arlington.

ASTM E1269-11, 2011. Standard Test Method for Determining Specific Heat Capacity by Differential Scanning., pp. 1-6, http://dx.doi.org/10.1520/E1269-11.2.

Barbosa-Cánovas, G., Altunakar, B., Mejía-Lorio, D., 2005. Introduction to freezing. In: Freezing of Fruits and Vegetables. FAO, Roma.

Brewer, M.S., Begum, S., 2003. Effect of microwave power level and time on ascorbic acid content, peroxidase activity and color of selected vegetables. J. Food Process Pres. 27 (6), 411-426, http://dx.doi.org/10.1111/j.1745-4549.2003.tb00527.x.

Carslaw, H.S., Jaeger, J.C., 1959. Conduction of Heat in Solids, 2nd ed. Oxford Science Publications, London.

Choi, Y., Okos, M.R., 1986. Effects of temperature and composition on the thermal properties of foods. In: Le Maguer, M., Jelen, P. (Eds.), Food Engineering and Process Applications, vol. 1. Transport Phenomena. Elsevier applied science publishers, pp. 93-101.

Comini, G., Del Guidice, S., Lewis, R.W., Zienkiewicz, O.C., 1974. Finite element solution of non-linear heat conduction problems with special reference to phase change. Int. J. Numer. Methods Eng. 8 (3), 613-624, http://dx.doi.org/10.1002/nme.1620080314.

Dima, J.B., Santos, M.V., Baron, P.J., Califano, A., Zaritzky, N.E., 2014. Experimental study and numerical modeling of the freezing process of marine products. Food Bioprod. Process 92 (1), 54-66, http://dx.doi.org/10.1016/J.FBP.2013.07.012. 
Dinçer, İ., Zamfirescu, C., 2015. Appendix B thermophysical properties of Water. In: Drying Phenomena., pp. 457-459, http://dx.doi.org/10.1002/9781118534892.app2.

Earle, R., 1988. Ingeniería de los Alimentos, 2da ed, ed, Acribia. Acribia, Zaragoza, España.

Fennema, O.R., William, D.P., Marth, E.H., 1973. Low-Temperature Preservation of Foods and Living Matter. CRC Press.

Fikiin, K.A., 1996. Generalized numerical modelling of unsteady heat transfer during cooling and freezing using an improved enthalpy method and quasi-one-dimensional formulation. Int. J. Refrig. 19 (2), 132-140, http://dx.doi.org/10.1016/0140-7007(95)00055-0.

Gebhardt, S., Thomas, R., 2002. Nutritive Value of Foods. USDA, Washington, DC, http://dx.doi.org/10.1111/j.1753-4887.1948.tb02035.x.

Giannakourou, M.C., Taoukis, P.S., 2003. Kinetic modelling of vitamin $\mathrm{C}$ loss in frozen green vegetables under variable storage conditions. Food Chem. 83 (1), 33-41, http://dx.doi.org/10.1016/S0308-8146(03)00033-5.

Glade, M.J., Meguid, M.M., 2015. A glance at broccoli, glucoraphanin, and sulforaphane. Nutrition 31 (9), 1175-1178, http://dx.doi.org/10.1016/j.nut.2015.03.003.

Gökmen, V., 2010. Selection of the indicator enzyme for blanching of vegetables. In: Enzymes in Fruit and Vegetable Processing. CRC Press, pp. 123-144, http://dx.doi.org/10.1201/9781420094343-c5.

Gonçalves, E.M., Abreu, M., Brandão, T.R.S., Silva, C.L.M., 2011. Degradation kinetics of colour, vitamin C and drip loss in frozen broccoli (Brassica oleracea L. ssp. Italica) during storage at isothermal and non-isothermal conditions. Int. J. Refrig. 34 (8), 2136-2144, http://dx.doi.org/10.1016/J.IJREFRIG.2011.06.006.

González-Hidalgo, I., Moreno, D.A., García-Viguera, C., Ros-García, J.M., 2018. Effect of industrial freezing on the physical and nutritional quality traits in broccoli. Food Sci. Technol. Int. 25 (1), 1-10, http://dx.doi.org/10.1177/1082013218795807.

Herr, I., Lozanovski, V., Houben, P., Schemmer, P., Büchler, M.W., 2013. Sulforaphane and related mustard oils in focus of cancer prevention and therapy. Wien. Med. Wochenschr. 163 (3-4), 80-88, http://dx.doi.org/10.1007/s10354-012-0163-3.

Hughes, T.J.R., 1987. The Finite Element Method: Linear Static and Dynamic Finite Element Analysis. Courier Corporation, Mineola,NY.

Jaskulski, M., Atuonwu, J.C., Tran, T.T.H., Stapley, A.G.F., Tsotsas, E., 2017. Predictive CFD modeling of whey protein denaturation in skim milk spray drying powder production. Adv. Powder Technol. 28 (12), 3140-3147.

Kidmose, U., Martens, H.J., 1999. Changes in texture, microstructure and nutritional quality of carrot slices during blanching and freezing. J. Sci. Food. Agr. 79 (12), 1747-1753, http://dx.doi.org/10.1002/(SICI)1097-0010(199909)79:12<1747:: AID-JSFA429>3.0.CO;2-B.

Lagrimini, L.M., Vaughn, J., Erb, W.A., Miller, S.A., 1993. Peroxidase overproduction in tomato: wound-induced polyphenol deposition and disease resistance. HortSci 28 (3), 218-221, http://dx.doi.org/10.21273/HORTSCI.28.3.218.

Lawless, H.T., Heymann, H., 2010. Acceptance testing. In: Sensory Evaluation of Food: Principles and Practices. Springer Science \& Business Media, London, pp. 325-336, http://dx.doi.org/10.1017/CBO9781107415324.004.

Lisiewska, Z., Słupski, J., Skoczeń-Słupska, R., Kmiecik, W., 2009. Content of amino acids and the quality of protein in Brussels sprouts, both raw and prepared for consumption. Int. J. Refrig. 32 (2), 272-278, http://dx.doi.org/10.1016/j.ijrefrig.2008.05.011.

McNaughton, J.L., Mortimer, C.T., 1975. Differential Scanning Calorimetry. The Perkin-Elmer Corporation, Connecticut, USA.

Miles, C.A., Van Beek, G., Veerkamp, C.H., 1983. Calculation of thermophysical properties of foods. In: Jowitt, R., Escher, F. (Eds.), Physical Properties of Foods. , pp. 269-312.

Morales-Blancas, E.F., Chandia, V.E., Cisneros-Zevallos, L., 2002. Thermal inactivation kinetics of peroxidase and lipoxygenase from broccoli, green asparagus and carrots. J. Food Sci. 67 (1), 146-154, http://dx.doi.org/10.1111/j.1365-2621.2002.tb11375.x.
Müftügil, N., 1985. The peroxidase enzyme activity of some vegetables and its resistance to heat. J. Sci. Food Agric. 5 (36), 877-880, http://dx.doi.org/10.1002/jsfa.2740360918.

Murasaki-Aliberti, N.D.C., Da Silva, R.M.S., Gut, J.A.W., Tadini, C.C., 2009. Thermal inactivation of polyphenoloxidase and peroxidase in green coconut (Cocos nucifera) water. Int. J. Food Sci. Tech. 44 (12), 2662-2668, http://dx.doi.org/10.1111/j.1365-2621.2009.02100.x.

Murcia, M.A., López-Ayerra, B., Martinez-Tomé, M., Vera, A.M., García-Carmona, F., 2000. Evolution of ascorbic acid and peroxidase during industrial processing of broccoli. J Sci Food Agr. 80 (13), 1882-1886, http://dx.doi.org/10.1002/1097-0010(200010)80:13<1882:: AID-JSFA729>3.0.CO;2-B.

Nesvadba, P., 2008. Thermal properties and ice crystal development in frozen foods. In: Evans, J. (Ed.), Frozen Food Science and Technology. Blackwell Publishing, Oxford, pp. 1-25, http://dx.doi.org/10.1002/9781444302325.ch1.

Nguyen, L.T., Tay, A., Balasubramaniam, V.M., Legan, J.D., Turek, E.J., Gupta, R., 2010. Evaluating the impact of thermal and pressure treatment in preserving textural quality of selected foods. Lwt-Food Sci. Techno. 43 (3), 525-534, http://dx.doi.org/10.1016/j.lwt.2009.09.022.

Nojavan, S., Khalilian, F., Kiaie, F.M., Rahimi, A., Arabanian, A., Chalavi, S., 2008. Extraction and quantitative determination of ascorbic acid during different maturity stages of Rosa canina $L$. fruit. J. Food Compos. Anal. 21 (4), 300-305, http://dx.doi.org/10.1016/j.jfca.2007.11.007.

Olivera, D.F., Viña, S.Z., Marani, C.M., Ferreyra, R.M., Mugridge, A., Chaves, A.R., Mascheroni, R.H., 2008. Effect of blanching on the quality of Brussels sprouts (Brassica oleracea L. gemmifera DC) after frozen storage. J. Food Eng. 84 (1), 148-155, http://dx.doi.org/10.1016/j.jfoodeng.2007.05.005.

Paciulli, M., Ganino, T., Pellegrini, N., Rinaldi, M., Zaupa, M., Fabbri, A., Chiavaro, E., 2015. Impact of the industrial freezing process on selected vegetables - part I. Structure, texture and antioxidant capacity. Food Res. Int. 74, 329-337, http://dx.doi.org/10.1016/J.FOODRES.2014.04.019.

Pietrak, K., Wiśniewski, T.S., 2015. A review of models for effective thermal conductivity of composite materials. J. Power Technol. 95 (1), 14-24.

Pérez-Calderón, J., Califano, A., Santos, M.V., Zaritzky, N., 2017. Kinetic parameters for the thermal inactivation of peroxidase and lipoxygenase in precooked frozen brassica species. J. Food Sci. 82 (6), http://dx.doi.org/10.1111/1750-3841.13717.

Peryam, D.R., Girardot, N.F., 1952. Advanced taste-test method. Food Eng. 24 (7), 58-61.

Rahman, M.S., Said Al-Saidi, G., 2009. Thermal conductivity prediction of foods. In: Shafiur Rahman, M. (Ed.), Food Properties Handbook. CRC Press, Boca Raton,FL, pp. 248-263, http://dx.doi.org/10.1201/9781420003093.

Richardson, T., Hyslop, D.B., 1985. Enzymes in food chemistry, In: Fennema, O.R. (Ed.), Marcel Dekker, Inc. New York, pp. $371-476$.

Rodriguez-Saona, L.E., Barrett, D.M., Selivonchjck, D.P., 1995. Peroxidase and lipoxygenase influence on stability of polyunsaturated fatty acids in sweet corn (Zea mays L.) during frozen storage. J. Food Sci. 60 (5), 1041-1044, http://dx.doi.org/10.1111/j.1365-2621.1995.tb06288.x.

Roos, Y.H., 1986. Phase transitions and unfreezable water content of carrots, reindeer meat and white bread studied using differential scanning calorimetry. J. Food Sci. 51 (3), 684-686, http://dx.doi.org/10.1111/j.1365-2621.1986.tb13911.x.

Sablani, S.S., 2009. Measurement of surface heat transfer coefficient. In: Shafiur Rahman, M. (Ed.), Food Properties Handbook. CRC Press, Boca Raton,FL, pp. 697-716, http://dx.doi.org/10.1201/9781420003093.

Santos, M.V., Lespinard, A., 2011. Numerical simulation of mushrooms during freezing using the FEM and an enthalpy kirchhoff formulation. Heat Mass Transfer 47, 1671-1683, http://dx.doi.org/10.1007/s00231-011-0831-7.

Santos, M.V., Vampa, V., Califano, A., Zaritzky, N., 2010. Numerical simulations of chilling and freezing processes applied to 
bakery products in irregularly 3D geometries. J. Food Eng. 100 (1), 32-42, http://dx.doi.org/10.1016/j.jfoodeng.2010.03.024.

Sumes, K., Deshmukh, R., Allied Market Research. URL https://www.alliedmarketresearch.com/frozen-vegetablesmarket. (Accessed 20 May 2019) 2018. Frozen Vegetables Market Outlook - 2025 [WWW Document].

Szymanowska, U., Jakubczyk, A., Baraniak, B., Kur, A., 2009. Characterisation of lipoxygenase from pea seeds (Pisum sativum var. Telephone L.). Food Chem. 116 (4), 906-910, http://dx.doi.org/10.1016/j.foodchem.2009.03.045.

Torregrosa Verdú, F., 2006. Determinación de vitamina C y carotenoides en zumos de frutas y hortalizas frescos, tratados por calor o por pulsos eléctricos de alta intensidad (PEAI). In: $\mathrm{PhD}$ Thesis. Universitat de València http://hdl.handle.net/10803/10068.

Williams, D.C., Lim, M.H., Chen, A.O., Pangborn, R.M., Whitaker, J.R., 1986. Blanching of vegetables for freezing - which indicator enzyme to choose. Food Technol. 40 (6), 130-140.

Workman, D., URL

http://www.worldstopexports.com/top-brussels-sproutsexports-by-country/). (Accessed 30 April 2019) 2018. Top Brussels Sprouts Exports by Country [WWW Document] 